\title{
PRIVATISING NETWORK INDUSTRIES
}

\author{
DAVID M. NEWBERY
}

CESIFO WORKING PAPER NO. 1132

CATEGORY 9: INDUSTRIAL ORGANISATION

FEBRUARY 2004

Presented at CESifo Conference on Privatisation Experiences in the EU November 2003

- from the CESifo website: www.CESifo.de 


\title{
PRIVATISING NETWORK INDUSTRIES
}

\begin{abstract}
Successful network utility privatisation requires incentive-based regulation that allows investment to be adequately rewarded form unsubsidised revenues while maintaining quality, and restructuring that permits effective competition for the network services. The potential for success and the size of the potential gains from privatising and restructuring vary by utility, with a ranking telecoms, gas, electricity, water and last, rail. There are doubts whether privatising rail deliver sustainable improvements. The paper gives evidence primarily from the UK, and surveys some of the international evidence. Real consumer prices for telecoms, gas and electricity fell in the UK, overcoming most opposition to privatisation.
\end{abstract}

Keywords: privatization, regulation, competition, telecoms, electricity, gas, water, rail.

JEL Classification: L33, L51, L91, L94, L95. L96.

David M. Newbery

Faculty of Economics

University of Cambridge

Sidgwick Avenue

Cambridge CB3 9DE

England

David.Newbery@econ.cam.ac.uk 
The privatisation of strategic and network industries is a relative instrument of public policy. How that instrument is used will depend upon the objectives of the government of the day. Just as tax and public expenditure policies can be used to improve efficiency, redistribute income, protect local interests such as farming, industry, coal mining or other favoured groups, so privatisation policies may be moulded by a desire to achieve a variety of goals. Standard economic rhetoric lays particular emphasis on increasing efficiency by reducing distortions and improving incentives. In the British case, additional objectives influenced the programme (Vickers and Yarrow, 1988, p157). The desire for wider share ownership was certainly intended to make reforms hard to reverse. Re-nationalisation would risk alienating the critical middle class swing voters in the electorate, quite apart from being fiscally expensive. Private ownership was considered one of the better ways of reducing the power of the trades unions, and with it the perceived support for the opposition Labour Party. Indeed, creating counterweights to the perceived monolithic unions meant that inadequate attention was given to dispersed control and competition in the early utility privatisations of telecoms and gas.

In other countries, creating national champions or increasing the power of the industrial oligarchy were intended or unintended consequences of the process of privatisation. Kornai's (1992) view that privatisation was needed to create "real owners" in Central and Eastern Europe was based on the premise that only by injecting the bacillus of private property into the Soviet body politic would a constituency to support the institutions of capitalism be created. While this view has a certain persuasiveness, it overlooks the historical evidence that efficient and sustainable institutions of capitalism may take a long time to mature with a poor allocation of initial wealth.

In South Africa, privatisation was actively discussed before the ending of apartheid as a mechanism to protect white interests and preserve at least the commercial if not political structures of pre-democratic South Africa. Conversely, the African National Congress stressed the importance of controlling the commanding heights of the economy as an essential component of the political transfer of power. (Lipton and Simkins, 1993) 
Given the wide range of objectives consciously or unconsciously pursued it would be surprising if all privatisations, and particularly those of network industries, were to achieve similarly high scores along the single access of improved efficiency. There is also a problem of endogeneity in assessing the success or otherwise of any privatisation. Those industries selected for privatisation, and those countries pursuing policies of privatisation, are unlikely to be a representative sample of industries and countries. Instead, candidates for privatisation are more likely to be performing badly by some criteria (losses, inefficiency, labour relations) and are quite likely to improve their performance in response to any coherent attempt to address these problems, so there is likely to be a sample-selection bias in studying privatisation cases. With these cautionary remarks, we can turn to the evidence to see how far it accords with theoretical predictions of might be expected of particular types of reform.

\section{Defining Privatisation}

The British definition of privatisation is the transfer of ownership and control by the state (central or local government) to private owners. In practical terms that means selling at least $50 \%$ of the voting shares, in most cases with the objective of selling $100 \%$, bearing in mind the financial advantages of selling in stages at successively higher prices. Even here the first tranche was invariably more than $50 \%$ of the shares as an irrevocable commitment to private control. If the state retains control then the enterprise has not been privatised. This raises an interesting question when state enterprises buy privatised utilities in other countries, like EdF buying London Electricity. Does this amount to renationalisation? Does London Electricity (now called EdF Energy) count as a private company or a state-owned enterprise? ${ }^{1}$

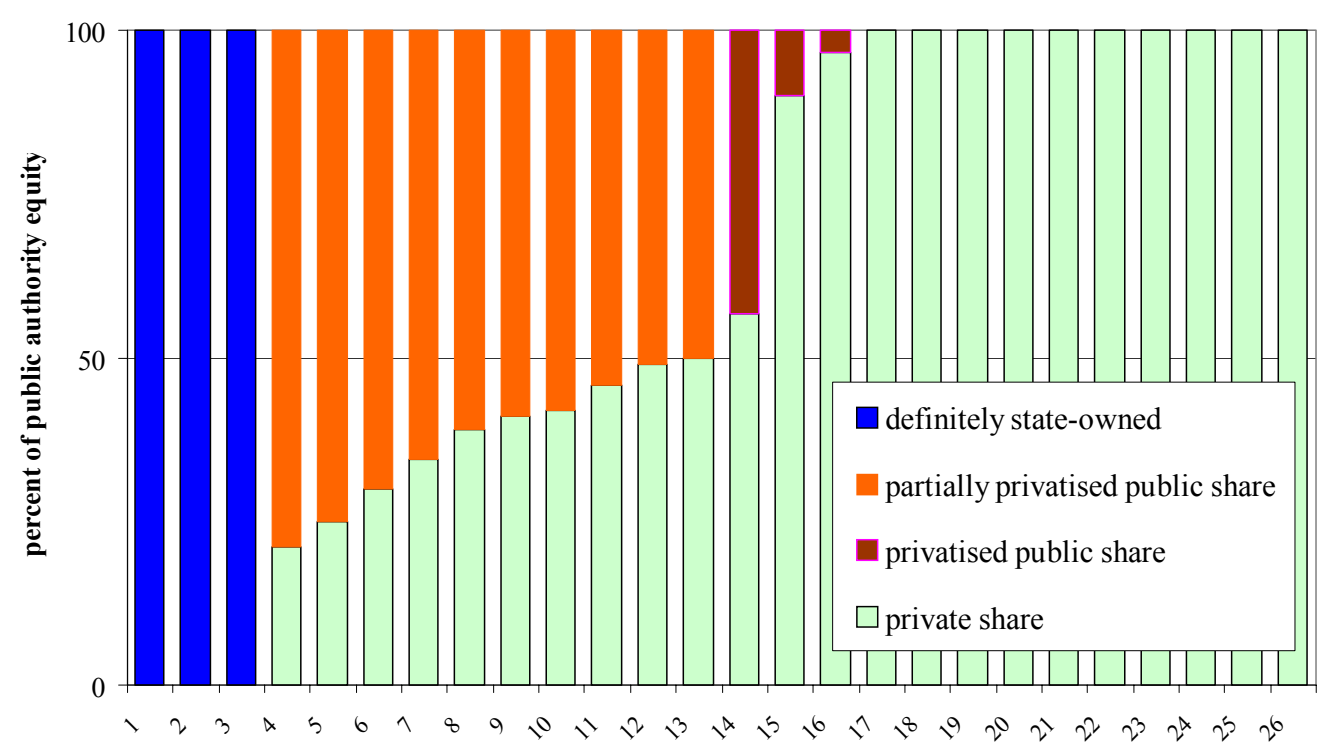

固 Figure 1 Public sector equity share in incumbent telephone operator in 2000

\footnotetext{
${ }^{1}$ The legal answer in Britain at least is that EdF Energy is deemed a private company.
} 
The issue is important, for Figures 1 shows that as late as 2000, Austria, Belgium, Finland, France, Germany, Greece, Luxembourg, Norway, Sweden and Switzerland all had above 50\% public ownership in telecommunications (Schneider and Jaeger, 2003, p108).

For wholly regulated utilities, this definitional issue may not raise practical difficulties, especially if it's a wholly owned subsidiary whose debt is not guaranteed by the parent state-owned company. Where state enterprises buy competitive companies abroad, (for example, generation companies, mobile phone companies or the like) there would be an obvious concern about state aids in the form of subsidised or favourable access to capital that might distort competition and arouse anti-trust concerns. Some governments, and certainly the British government, retained a Golden Share when privatising companies. These carried veto rights over subsequent changes of ownership, possibly for a limited period, to ensure that the objectives of dispersed share ownership and possibly ownership by a majority of nationals would be protected. Golden shares could also be used to prevent take-overs by state-owned-enterprises abroad, but have been attacked by the European Union as restricting capital market liberalisation.

Network utilities such as telecoms, gas, electricity, water and rail, are characterised by a natural monopoly network which is essential for the delivery of network services to final consumers. Most network utilities involve large sunk investments delivering essential services to the mass of the voting population, who are therefore concerned to protect themselves against the unregulated exercise of market power that a natural monopoly makes possible. Those asked to invest in the utility will be concerned that the resulting powerful political lobby will argue for low prices after any investment has been irrevocably sunk, making investment unattractive. (Gilbert and Newbery, 1996). Although most network utilities were originally built by private investors, they were only successfully retained in private ownership where the institutions of capitalism evolved politically sustainable forms of regulation that protected the interests of both investors and consumers (Newbery, 2000).

The default resolution of the conflict between consumers and investors in most countries was public ownership providing access to investment funds and political control over final prices. The natural form of most of these utilities under both public and private ownership was as a vertically integrated franchise monopoly. Final prices were regulated under both private and public ownership at the cost of service (also known as rate-of-return regulation), reinforcing the commitment to both protect owners and consumers from exploitation. Such regulation was inefficient, except in those cases where rapid technical progress allowed costs to fall and rate reviews were delayed allowing prices to remain steady, mimicking the effects of price-cap regulation.

\section{The new model for structure and regulation}

Criticisms of the inefficiency of rate-of-return regulation for encouraging gold-plating and cost inefficiency (Averch and Johnson, 1962) became cumulatively decisive in the liberalisation movement in the United States. In Britain, privatisation was primarily driven by more political motives, to "roll back the frontiers of the State" and because "the business of government is not the government of business" (Lawson, 1992). The early success of the 
Thatcher government in privatising normally commercial activities such as oil, cars, transport, and defence industries raised no obvious regulatory or competitive issues, but the announcement to privatise BT in 1982 inevitably raised the question of how such a network monopoly would be regulated. Professor Stephen Littlechild was commissioned to propose a system of regulation. He saw the task as avoiding the inefficiencies of cost of service regulation, creating incentives for improved efficiency while restraining market power, and providing a transitional period of regulation until the industry became competitive (Littlechild, 1983; Bartle, 2003). Thus was price-cap regulation, or RPI-X, developed and with it the supporting institutions of independent regulation and licenses subject to periodic review.

The emphasis in the earlier utility privatisation in Britain was on the transfer of ownership and improved regulation of the natural monopoly network, rather than the pressure for liberalisation and competition that drove the very different reforms in America, where utilities were already in private ownership. BT was therefore privatised without restructuring, facing a small competitor with a protected duopoly status that was guaranteed until the Duopoly Review of 1991. British Gas was privatised in 1986 as a completely vertically integrated utility, owning gas fields in the North Sea (though also buying at the beachhead from other oil and gas companies), owning the high pressure National Transmission System, all storage facilities, all local distribution networks and the retailing business.

Economists had always been critical of transferring public monopolies into private monopolies, and Littlechild specifically designed price-cap regulation has a transitional device to a competitive market that would no longer need regulation. The break up of AT\&T in the United States with the Modified Final Judgement of 1984 exposed the once monolithic Bell telephone company to competition for long distance calls, although the local Bell Operating Companies retained their franchises. Economists such as Vickers and Yarrow (1988) stressed the distinction between privatisation, or the transfer of ownership, and liberalisation: the introduction of competition for the network services supplied over the network.

Liberalisation would need the potentially competitive network services to be able to access the natural monopoly network, and here two models were on offer. The incumbent utility could continue to own the network and also provide network services, but other entrants would be allowed access to the network and could compete with the incumbent. This was the intention with BT and is the standard model for telecoms privatisations in most countries. The alternative more radical solution is to separate ownership of the network from ownership of the network service companies. Such structural unbundling removes the risk that the incumbent can favour its own network services and impede entry to gain competitive advantage, but risks losing economies of scope between the network and network services. These were arguably considerable in the case of telecoms, where the operator of a switched network has to create end-to-end connectivity and at the same time calculate the cost of the call in order to bill the customer. The design of switches to route and record such information have natural synergies that would take considerable investment and design to replicate at comparable cost in unbundled form. 
In contrast, there were no obvious reasons why gas production, gas transport, gas storage, local gas distribution and retailing should all be provided by the same incumbent, particularly, as in the case of Britain, once the high and low pressure pipeline system was mature. The history of the restructuring of British gas is one of 15 years regulatory pressure from successive investigations by the Office of Fair Trading and the Monopolies and Mergers Commission (Newbery, 2000). Increasingly onerous regulatory conditions were then imposed, finally leading British Gas to accept that it would commercially prudent to separate first the operation and then the ownership of these various activities.

By the time the Government started thinking about privatising the Electricity Supply Industry (ESI) towards the end of the 1980s, the message that the public did not like private monopolies had become loud and clear. Economists argued that competitive pressures were more likely to deliver cost improvements and hence politically attractive price reductions. The new guiding principle was to restructure to introduce competition where possible, and to simulate as far as possible the effect of competition on the natural monopoly network through price-cap regulation. Subsequent privatisation acts laid down the duties of regulators to promote competition where possible, and the architects of restructuring were increasingly required to create structures that maximised the opportunities for competition.

This gradual change in emphasis from privatisation as purely a transfer of ownership to privatisation combined with restructuring to introduce competition took time. The decisive turning point came in 1990 with the restructuring of the Central Electricity Generating Board (CEGB), the vertically integrated generation and transmission company that supplied electricity to England and Wales. The CEGB was divided into four companies, National Grid, National Power, PowerGen, and Nuclear Electric (the last remaining in public ownership as the custodian of nuclear power stations whose net asset value was extremely uncertain). The two privatised fossil generators, who set the price over $95 \%$ of the time, had between them $80 \%$ of capacity, divided in the ratio 3:2 between National Power and PowerGen. The highly concentrated form of the industry was the result of earlier attempts to place all the nuclear power stations into one large company able to manage the remaining uncertainties (National Power, then described as BigG). That encouraged the creation of one sufficiently large competitor (LittleG), to supposedly countervail the resulting market power. Once the City deemed nuclear power unsalable, the planned restructuring was too far advanced to return to earlier proposals of five equal-sized fossil generating companies.

The subsequent history of competition in England and Wales has been told many times (Newbery, 2000; Newbery and McDaniel, 2003) and is again a history of regulatory pressure and government/competition authority bargaining to introduce further competition. Briefly, and identifying the key decisions, the companies were privatised with three-year contracts for the sale of electricity and the purchase of coal. These contracts reduced the incentive to manipulate the spot or wholesale price in the market (the Electricity Pool) that had been created to trade electricity between generators and suppliers. Once these contracts expired the coal contracts collapsed, the price-cost margin widened dramatically and the attractive wholesale price induced a "dash for gas". The architects of privatisation had anticipated the unsatisfactory market structure and had put in place relaxed regulations on the 
distribution companies (the Regional Electricity Companies, or RECs) that allowed them to collaborate to set up "independent" power producers who could enter the industry and thus reduce concentration. The persistence of high and growing profit margins caused the regulator to impose a price cap on the two generators, that would be lifted only if they sold $6,000 \mathrm{MW}$ of plant (about 10\% of peak demand). This they did in 1996, but high profit margins persisted and led to calls to reform the wholesale electricity market (Newbery, 1998).

Meanwhile, the duopoly generators perceived the risk-reducing attractions of integrating downstream into retailing, and proposed merging with RECs. The mergers were referred to the Monopolies and Mergers Commission that found them against the public interest. The Secretary of State then prevented the proposed mergers. Subsequent negotiations traded off horizontal concentration for vertical integration, and by the end of the decade the generation industry was supplied by the equivalent of eight comparably sized companies (most vertically integrated into supply, which became more concentrated), as well as experiencing excess capacity as a result of excess entry. The resulting collapse of prices finally delivered the benefits of competition that a more competitive initial structure would have produced more rapidly.

The two vertically integrated regional Scottish companies were privatised unchanged, and their relatively poorer efficiency performance demonstrated the importance of separating the ownership of generation, transmission and distribution. In the much smaller system in Northern Ireland, the three main power plants were sold to three separate companies with long term power purchase agreements signed with the monopoly transmission, distribution and supply company acting as a Single Buyer. These contracts provided powerful incentives to increase availability and drive down costs, but the cost reductions could not be passed on in price reductions given the long-term contracts.

The UK ESI therefore demonstrates the power of competition in first driving down costs, and then, where competition could became effective, in driving down prices, as described further below.

The water and sewerage companies of England and Wales, but not Scotland, were also privatised in 1990 with provisions that would allow a modest degree of competition to develop, but retaining the vertically integrated structure for the most part. (In some areas, relatively small water only companies retained their form, with the sewerage services provided by the larger regional companies.) Competition of any form was extremely slow to develop. This was mainly because the cost of moving water any distance is high compared to its value, and because the incumbent was responsible for ensuring the specified high quality standards. Water utilities were therefor reluctant to accept and transport competitor's water without also controlling the management of water from source to final delivery.

The full consequences of the pursuit of competition as the key element of privatisation were realised in the restructuring of British Rail from 1994 to 1996. That previously monolithic company was fragmented into over 100 different companies. The core track company (Railtrack) bought services from a variety of maintenance companies, and the 25 train operating companies (TOCs) lease their equipment from three rolling stock leasing 
companies, who in turn contract out the building and maintenance of these assets. Competition on the rails was considered desirable but difficult, so the alternative of competition for the market was chosen. TOC franchises (typically for 7 years) were to be bid with the best value (least subsidy for specified quality) being awarded in the expectation that this would deliver lower costs and prices. Competition would also be introduced between the suppliers of services and new rolling stock selling to leasing companies or, in some cases, directly to TOCs. Early attempts at encouraging competition on the rails were quietly shelved, to reduce the commercial risks facing the TOCs, and because they were clearly more difficult and costly than the likely gains warranted.

The apparently modest rail accident at Hatfield in 2000 in which four passengers died revealed an alarming gap between the ownership and operation of the network, and the critical maintenance needed to ensure its safety and reliability. The subsequent effective bankruptcy of Railtrack, the huge increases in costs of repairing and replacing the network, demonstrated that the initial restructuring had been over-ambitious and had failed to recognise the important synergies between track ownership and track maintenance.

\section{Privatisation and liberalisation}

Privatisation and liberalisation are distinct policies, but while it is possible (and regrettably common) to privatise without liberalising, it is less clear that one can liberalise without privatisation. The core network will, in most cases, remain a regulated natural monopoly, and as such not subject to competition. There is no obvious reason why an unbundled core network should not remain in public ownership, while network services are privatised. Several countries, such as the Netherlands, have retained the national grid in public ownership, while allowing private ownership in generation. Similarly, it is quite common for gas and electricity distribution networks to be municipally owned, with private ownership elsewhere. After the collapse of Railtrack, the British Government created Network Rail, a not-for-profit-distribution public-private partnership, a quasi-commercial public entity that is a compromise between the desire to renationalise and a desire to keep the debt off the public sector's balance sheet. Roads are almost entirely in public ownership while transport services are almost entirely privately supplied.

The main case for privatising networks like the grid is that they can be more effectively exposed to profit-related incentives, while at the same time clarifying the nature of regulation, and separating the regulatory and ownership functions. The alternative view is that the state can better pursue its interests by direct control through ownership than by indirect control through regulation, which involves an additional principal-agent relationship that introduces a further layer of potential inefficiency. This argument would not apply to a choice between bureaucratic control and the market, which would seem to require independent owners to ensure effective competition and hence rule out state ownership, as discussed below. It does carry some weight when comparing public or private ownership of a natural monopoly, where the issue is primarily of the quality of regulation and incentives under the two forms. 
The modern approach (e.g. Sappington and Stiglitz, 1987) is that the owner is the authority with the residual rights, that is, those rights that are not subject to contract or control. Regulation limits the actions of privatised networks, but cannot specify their actions in full detail, leaving considerable discretion to the private owners. In a state-owned enterprise, the state may delegate day-to-day control to the management, who may report to a board that has considerable autonomy, but the state as owner retains the right to intervene directly. Sappington and Stiglitz (1987) argue 'that the main difference between them (i.e. public and private ownership) involves transaction costs the government faces when attempting to intervene in delegated production activities. Government intervention is generally less costly under public ownership, but a promise not to intervene is more credible under private production, and it can also have beneficial incentive effects.'

Ownership affects the ability to control the behaviour of the utility, so that the objectives of the owner matter. The standard but oversimplified assumption is that private firms maximise profit (subject to regulatory constraints), while state-owned enterprises pursue 'the national interest', normally interpreted as maximising social welfare. In both cases there is a principalagent problem to ensure that managers act in the interest of owners, and the private sector typically finds it easier to do this via stock options, although there are precedents for linking managerial pay to profits in state enterprises (Network Rail provides one example, although is not exactly state-owned). In addition, publicly quoted companies are subject to the capital market disciplines of take-over, bank monitoring over debt, and bankruptcy, all of which encourage the pursuit of profit, and discourage costly managerial discretion. State-owned networks lack the hard budget constraints associated with bankruptcy, reducing the state's ability as regulator/principal to commit to future penalties. It might be thought private networks cannot be bankrupted, but Britain forced Railtrack into administration (effectively bankruptcy), underlining the difference between public and private ownership.

State-owned networks have managers subject to monitoring by boards, appointed by the owner, the state, who should be better placed to exercise control as there is no free-rider problem that affects individually small shareholders (Vickers and Yarrow, 1988). The argument can be pushed further back to ask whose interests the state represents, and specifically why the state should wish to maximise social welfare. In addition, we need to know what objectives the regulator has, and how far these constrain the actions of the private utility. If regulation represents the same interest groups that influence the government, then the differences between public and private ownership are more a function of the form of regulation or oversight. Obvious differences are that privatised networks have more managerial discretion, but are only subject to periodic review, and normally operate within a well-specified regulatory framework (e.g. licence conditions, price-caps, quality standards, protection against entry, universal service obligations). State-owned networks might have contracts specifying their obligations (as in France), rather like licence conditions for privatised networks, but these contracts can be renegotiated in their entirety, whilst the licences of privatised networks can often only be renegotiated with the agreement of the utility. The difference is thus one of the degree of commitment to future regulatory or monitoring behaviour, and it can be exaggerated - some systems of regulation lack commitment, while some public utilities may be given very 
considerable autonomy and operate on the expectation that this will continue. Well-designed and credible regulation offers the prospect that poorly managed state-owned networks might do better under private ownership, and privatisation in that case represents a commitment to placing commercial objectives above other objectives that are better pursued by different policies.

The next question is whether it is possible to sustain competition under public ownership for the network services, where markets offer distinctly different incentives to bureaucratic control. Is privatisation a necessary step to market liberalisation? The most powerful force for improved efficiency is the incentive to drive down costs combined with safeguards to ensure the desired quality of service. Competitive markets in which consumers make informed decisions between alternative suppliers satisfy both requirements. In competitive markets, firms can only increase profits by driving down costs or improving the attractiveness of their product or service. Competition encourages efficiency and innovation. Effective competition passes on these cost reductions in lower prices.

Public ownership might be compatible with competition either with investor-owned utilities (common in the United States), or between different companies, all of which are state (or municipally) owned. If competition is to deliver efficient outcomes, then participants need to face hard budget constraints and have access to inputs, especially labour and capital, on the same terms. Municipal utilities in the United States enjoy tax-free bond finance and so have a lower cost of capital than investor-owned utilities, while until recently many Continental utilities were exempt from company taxation. These distortions can be corrected, but even if they are, state enterprises that can borrow at the risk-free Government bond rate and hence undercut equally efficient private competitors. They are effectively protected from the threat of take-over or bankruptcy, which lowers the cost of debt, but may reduce the incentives for efficiency. The combination of these various factors means that either the lower apparent capital costs of public ownership are dissipated in lower efficiency (or higher wages for public sector workers), allowing an inefficient equilibrium, or that the public cost advantages make private competition unviable.

The case has been made (Cremer, Marchand and Thisse, 1989, Willner, 2003) that if state-owned companies are charged to compete with private companies, they may discipline private competitors who would otherwise be able to exercise market power (or reduce quality). This is definitely second best, for if both types of firm survive, the publicly owned company must be productively inefficient (excess capital-labour ratios and inefficiently bureaucratic management). The gain then comes from reduced market power or superior quality. This is an indirect form of competition policy, better replaced by structural and regulatory reforms where possible (and privatisation offers a unique opportunity for getting this right).

Most examples of competing public utilities appear to be transitional forms evolving out of regional franchises provided by municipally-owned utilities. Full competition requires contestable entry (and the possibility of exit); making competition between different stateowned service providers suspect, although different municipally owned companies might be able to compete in each others markets, as in Norway. At first glance, it is very difficult to see what advantages state or municipal ownership provides for contestable service provision, 
in contrast to the ability to impose universal service obligations and other social objectives on publicly owned natural monopolies.

The one potential argument for retaining public ownership of potentially competitive network services is that it would be difficult to sustain competition that was sufficiently strong to pass on full cost reductions to domestic consumers, while meeting other objectives such as security of supply and universal service obligations. Thus the latest Energy Directive (2003/54/EC which came into effect in August 2003) anticipates full domestic liberalisation by 1 January 2007, although this decision is subject to review. This would end the domestic franchise and allow domestic customers the same rights as all other (larger) customers to choose their supplier. On the British model, suppliers would be unregulated, and would be able to go bankrupt (and indeed, on several occasions have done so). There are considerable doubts whether the costs of liberalisation are worth the benefits (Green and McDaniel, 1998). If consumer inertia allows incumbent suppliers to increase their profit margins, and if they dissipate any efficiency gains in additional marketing costs, then the social costs of full liberalisation would exceed the benefits. Ending the franchise could also shorten contract periods and may thereby raise the cost of capital for providing new electricity generating capacity or investments to find and transport gas.

If a full social cost-benefit analysis shows that unregulated supply competition is inferior to regulated supply, then the case for unbundling supply from distribution is weakened, and in that case distribution companies would retain a franchise and hence a local monopoly. The earlier argument for continued public or municipal ownership might then hold. In this case, competitive and private suppliers to the non-franchise market would be competing with the vertically integrated franchise company. It seems quite likely that the low capital costs of an agile supply business competing for commercially astute customers could survive in competition with a publicly owned distribution and supply company.

This argument does not refute the claim that liberalisation requires privatisation, for the only case for public ownership here is the apparent efficiency of continued monopoly provision. Certainly in Britain it was not taken as an argument for keeping the distribution companies in public ownership, and their performance has improved relative to the counterfactual of continuing under public ownership (Pollitt and Domah, 2001).

\section{Determinants of successful utility privatisation}

The critical enabling condition of successful utility privatisation is whether a system of regulation can be designed that provides good incentives for delivery of services of the right quality while reassuring investors of the profitability of economically justified investments. This issue of credibility is a key stumbling block to privatisation in many developing countries, where the reputation of the government for efficient management is low, and where the regulatory institutions and supporting legal and constitutional protections are inadequate or untested. A number of authors have confirmed this for the electricity supply industry (which, as argued below, is particularly dependent on good regulation). ${ }^{2}$ They find

\footnotetext{
${ }^{2}$ Bergara, et. al, (1997); Holborn, (2001); Zelner and Hensiz, (2000)
} 
that the amount of private investment is positively correlated with institutional factors that support credible reform, such as the protection of property rights, judicial and regulatory independence, and country political risk. The first determinant of success is therefore the extent to which credible regulation is a key determinant of success.

The second determinant of success is whether the network would perform better under price-cap or incentive regulation than under the de facto cost-of-service regulation characteristic of the public sector. The main problems with price-cap regulation are maintaining the efficient level of quality, and providing efficient investment incentives.

The third issue is whether the prices charged under public ownership are sufficient to cover operating costs and a return on any new investment that will be required. If prices are above avoidable costs but below long-run marginal costs, then, as with the British water industry, it is possible to gradually increase prices to the level at which they can earn a market return on new investment while providing some return to the existing assets. The existing assets will be valued at the return they are allowed to earn, which in the case of British Water was less than one-tenth of their replacement cost. If, as in much of Central and Eastern Europe, prices were below avoidable costs, few private owners will be willing to buy them unless they believe that costs can be driven down below the prices they are allowed to charge. One of the constraints affecting the ease, speed and political support for privatisation will be the direction in which prices have to move after privatisation to reach competitive levels. In Britain for gas, electricity and telecoms, competitive prices were lower than the previous prices, and privatisations were popular. In the case of water, prices had to increase and privatisation was relatively unpopular, as it was for energy companies in transition and developing countries.

All of these conditions are necessary for success, but may not be sufficient to deliver improved social welfare. That will depend on whether the new structure provides better incentives for efficient operation and investment.

\section{The critical importance of competition}

The evidence from the growing number of utility privatisations points to a number of features that make privatisation more likely to be socially profitable, and other features that raise significant challenges, although not necessarily arguing against privatisation. Effective competition with informed consumers is a powerful force to drive down costs and safeguard quality. The major determinant of beneficial privatisation is whether the industry is capable of sustaining effective competition, and whether the prospects for innovation are promising or minimal. Unbiased competition is more likely if the network services can be unbundled from the network. If the synergies or economies of scope between the network and the services are very strong, vertical integration has lower costs than an unbundled industry, which may outweigh the benefits from introducing competition. Liberalisation without unbundling is an intermediate step that may achieve the best of both worlds but could experience the worst of both worlds.

The next question is whether the market structure created at privatisation will allow enough competition to pass on the cost savings in lower prices to final consumers. If the 
incumbent remains vertically integrated and entrants are allowed to use the network, then the market structure may be so concentrated that continued asymmetric regulation is required, with the risk of distorting competition and losing potential efficiency gains. The ideal set of circumstances is one in which the synergies between network and services are low, and there is excess capacity in service provision, with few economies of scale. In that case it is possible to create a sufficient number of competing service companies while the spare capacity restricts their ability to raise prices above costs. One way of measuring market power, is to ask whether, if all other competing service providers operate competitively, the residual largest supplier is required to meet maximum demand, or whether his customers can satisfy demand without his presence. If demand is fairly inelastic, as in electricity, and if the largest producer is required to meet demand then that largest producer will have substantial market power, at least in periods of high demand.

\section{The potential for and experience of success for different utilities}

Perhaps not surprisingly, the order in which the UK (and many other countries) privatised its utilities is almost the rank order of the likely social benefits of privatisation.

\section{Telecoms}

BT was the first British privatisation in 1984 (Parker, 2003), and Wellenius and Stern (1994) demonstrate that reforms were well advanced in developed, transitional and developing countries by the early 1990s. Galal, Jones, Tandon and Vogelsang (1994) provide more case studies of telecoms privatisations than any other utility. There are excellent reasons for this popularity. First, regulatory credibility is less of an issue, as the regulatory compact (the utility invests in return for an assurance that it can earn a return on the investment) is almost self-enforcing. The normal problem with regulatory credibility is that regulators (or ministries controlling prices) view the gains from lower prices as greater than the possible future discouragement to investment. If demand is growing strongly, investment needs are high, and the public sector finds it difficult to finance such investment, then the balance of advantage shifts towards the utility investors. All of this is true for telecoms, particularly where demand has been suppressed and waiting lists are long.

In addition, international telecoms companies bring managerial and technical expertise lacking to most domestic companies, and can credibly threaten to seriously degrade performance if they do not continue to maintain the software and equipment, quite apart from the need of any country to secure interconnection with telecoms companies abroad. Finally, in many countries telephones are a luxury service, relatively price insensitive, and consequently potentially very profitable, making them attractive purchases. For all these reasons, the costs of reneging on the terms of a telecoms privatisation are likely to be far higher than any temporary benefits, reassuring investors. Indeed, the prospect of attractive profits for telecoms companies are partially reflected in the large bids companies are willing to make for the right to enjoy these profits. ${ }^{3}$

\footnotetext{
3 Thus GTE bid US\$1.8 billion for 56\% of Puerto Rico Telephone, which has 1.5 million lines,
} 
Not only is it relatively easy to sell telecoms companies, but there is a growing belief, supported by evidence, that adequate investment in telecoms infrastructure is critical to economic growth (Roller and Waverman, 2001). The previously common structure of placing post and telecommunications under a government ministry is then seen as a recipe for inadequate investment, delayed modernisation and suppressed innovation. Separating out telecoms from post, followed by commercialisation and privatisation, is the obvious solution to both problems. The main problem with telecoms privatisation is thus not one of regulatory credibility, nor even of convincing governments of its desirability, but rather securing a reasonable proportion of the potentially large gains on offer for the public good. This requires the design of effective regulation and liberalisation so that the gains from more efficient operation and investment are translated into lower prices and reduced deadweight loss.

Over time, the cost of long-distance and international calls has fallen far faster than the cost of the local loop (or the "last mile") connecting consumers to the nearest switch or exchange. The relentless operation of Moore's law on switches (halving micro-electronic costs every 18-24 months), and the rapid increase in capacity with fibre optic cables have driven down unit costs, compared to the labour-intensive provision of the twisted copper pair in the local loop. Under public ownership (or state regulation in the US), it was politically attractive to cross-subsidise local calls from the profits on long-distance calls. The situation for international calls was even worse, for each country's single telephone company owned cross-border links up to the mid-point (or border), and so each could separately set the charge for call completion, resulting in prices above joint-profit maximising levels. As the elasticity of demand for such calls is high (greater than one), the deadweight losses of excessive margins are extremely high compared even to the high profits.

As an example, in 1995 the UK made 1.025 billion minutes of international calls to the United States at an average price of 55 US cents per minute and an average cost of 8.57 cents per minute (Mason, 1998). The price was therefore nearly seven times cost, largely as a result of the international settlement system. The profit on this single route generated by this distorted price was US\$481 million per year. The potential consumer surplus of lowering price to cost would have been US $\$ 1,050$ million dollars at a price elasticity of demand of unity, implying a deadweight loss of $\$ 569$ million per year, greater than the profits. These numbers are large, particularly when scaled up by the global telecoms revenue for the UK (domestic and all international calls, not just those to the US) of \$27.6 billion (WTO, 1998). At plausibly higher elasticities the deadweight losses would be even higher.

In addition, economies of scope argue for vertical integration between the network and service provision, at least at the regional level (in the US), and possibly at the national level in geographically smaller countries. Competitors offering long-distance and

while Tisa bid $\$ 1.925$ billion, suggesting a price of nearly $\$ 2,300 /$ line $(F T, 15 / 7 / 98)$. Wellenius (1994) reports bids varying from US\$700/line for the earlier Chile privatisations, up to $\$ 3,300 /$ line for Venezuela in 1991, compared with the cost of building a network of perhaps $\$ 1,000-\$ 1,500$ per line. Bids for mobile telephone companies (before the dot-com crash) were three or more times asset value, reflecting the value of the customer base and its associated profit stream. 
international calls need access to the local loop, and it was rapidly learned that leaving this to bilateral negotiation between incumbent and entrant would either result in entry deterrence or collusive pricing, even at above profit-maximising levels (Armstrong, 1996, 1998; Laffont Rey and Tirole (1998a, b; Vogelsang, 2003). Access prices therefore need to be regulated, at least until the incumbent fixed-line operator ceases to possess Significant Market Power, as defined by the EC Communications Directives (2002/21/EC, Art. 14). Regulating access pricing is made more complicated by the complexity of the cost structure of telecoms, itself a consequence of rapid technical progress. The British telecoms regulator, Oftel, worked with industry groups for over a decade to reach agreement on cost modelling and cost allocation, and disputes continue to complicate regulation (Competition Commission, 2003). In the US, tensions between the federal regulator, the FCC, concerned to create efficient competition, and state public utility commissions anxious to preserve cross-subsidies to local calls and provide various extensions to universal service obligations, have resulted in inefficient regulation. Again, as elasticities are quite high and price-cost margins may be significantly distorted, regulatory inefficiencies can be very costly (Hausman, Tardiff and Belinfante, 1993; Crandall and Waverman, 1997).

The inefficiency of public ownership or poorly regulated private ownership does not end with the overpricing of some services. Hausman (1997) argues that one of the most costly consequences of traditional regulation as practised in the US is the delay hindering the introduction of new services, caused by concern that these new services might be crosssubsidised from the captive customer base. Hausman gives two examples - voice messaging and cellar phones. AT\&T originally wished to offer voice messaging in the late 1970s, which the FCC delayed until 1986 and which were finally allowed in 1988, when they were immediately introduced. The estimated consumer surplus they generated is estimated at US\$1.27 billion per year by 1994 (the estimated price elasticity of demand for messaging was -1.6), so the ten-year regulatory delay cost billions of dollars. Hausman further argues that a possible ten-year regulatory delay in introducing mobile phones might have cost consumers as much as $\$ 100$ billion, large compared with the 1995 US global telecoms revenues of $\$ 180$ billion.

The consequences of regulatory design are nicely illustrated by the two case studies of Latin American telecoms privatisations in Galal, Jones, Tandon and Vogelsang (1994). The Chilean company, CTC, was in private ownership until 1970, and was reprivatised in 1987, but was subject to benchmark regulation from 1977. The benchmark in this case was an ideal efficient model firm used to set the price control. As the price cap is unrelated to the firm's own costs, the incentive effects are more powerful than the standard form of RPI-X price-cap developed in Britain, where periodic reviews relate the cap at least in part to the firm's actual costs. This novel approach of incentive regulation, already well-established before privatisation, avoided many of the problems of securing the potential benefits of privatisation. The social costbenefit analysis of CTC showed present discounted social gains of over $140 \%$ of base-year revenues, largely secured by domestic consumers. In contrast, the privatisation of the Mexican company Telmex failed to secure the productivity improvements for the domestic economy as a result of poorly designed regulation. That regulation was perceived to lack credibility, resulting 
in underpricing, so that most of the benefits flowed abroad to foreign shareholders, causing an overall loss in present discounted social welfare of $13 \%$ of base-year revenues. ${ }^{4}$

Wallsten (2002) studies a panel of 200 countries from 1985-1999 to examine the impact of sequencing of reform on investment, and a smaller sample to examine the effect of regulatory reform on privatisation proceeds. Wallsten finds that countries that established separate regulatory agencies before privatisation experienced more investment, more penetration of both fixed line and mobile telephony, and realised higher sales prices. Gutiérrez (2003) also finds that sound regulatory governance has a positive impact on telecoms network expansion and efficiency in a panel of 22 Latin American countries from 1980-97.

If regulation is inefficient, and if excessive pricing produces such high deadweight costs, then the obvious solution is to replace regulation by competition where possible. Britain provides an early example of the potential gains from opening up the market. The Telecommunications Act 1981 separated British Telecommunications (later BT) from the Post Office and ended its statutory monopoly over the network. The small company Mercury was licensed in 1982, but BT was privatised in 1984 without restructuring, as the sole owner of the network, under the regulation of Oftel. Mercury was licensed as the sole competitor until 1991. The duopoly was reviewed in 1990, and terminated in 1991 with any application for a licence thereafter to be considered 'on its merits'. By 1995 there were over 150 operators licensed to compete with BT, including 125 cable TV companies who could offer telephony with cable, of which 80 were actually providing service, (Bell, 1995). Rapid entry was followed by substantial consolidation, but by 2003 cable companies had more than half the broadband market, with BT supplying most the rest by ADSL.

The failure to create a more competitive structure at privatisation and the delay in allowing competition led Armstrong, Cowan and Vickers (1994) to the judgement that 'the duopoly policy has been detrimental to development of competition, and its main beneficiary has been BT itself' (p.240). This does not mean that privatisation was undesirable - only that opportunities were lost (though they may not realistically have been available). Galal, Jones, Tandon and Vogelsang (1994) provide a cost-benefit analysis of the privatisation of BT based on data to 1990. They concluded that privatisation benefited shareholders, government, and consumers as a whole, though business consumers did substantially better than residential consumers, many of whom may have suffered a net loss. The main sources of these benefits were changes in prices and improvements in the rate of investment once the constraints imposed by state ownership were removed.

Newbery (1997) demonstrated that until 1991, BT's labour productivity did not appear to change compared to the experience of comparable companies elsewhere, though there was a

\footnotetext{
${ }^{4}$ In both cases social welfare is a weighted sum of the various gains, as explained in Newbery (2000, p119), and these differ from the 'net change in welfare' recorded in the original source.

5 This study tests for, and finds, endogeneity; that is, telecoms performance affects the choice of reforms, as well as the more normally tested effect of reforms on performance. He criticises Wallsten for neglecting this feedback and thus tending to exaggerate the impact of privatisation and regulation on performance.
} 
sharp improvement in 1992 after the Duopoly Review. Martin and Parker (1997) find the same. Boylaud and Nicoletti (2001) use an international database to study the impact of entry liberalisation and privatisation on productivity, prices and quality of service in long-distance and mobile telephony in 23 OECD countries between 1991 and 1997. They find that that prospective competition (as proxied by the number of years remaining to liberalisation) and effective competition (as proxied by the share of new entrants or by the number of competitors) both bring about productivity and quality improvements and reduce prices. Perhaps surprisingly, they found no clear evidence that the ownership structure (measured by the state share and years remaining to privatisation) affected performance. This is consistent with the view that competition rather than ownership is the key determinant of success, but apparently not with the view that successful pressure for privatisation is strongest where performance under public ownership is worst, and where improvements are most likely. ${ }^{6}$ If we accept that liberalisation requires privatisation, then it would be difficult to disentangle these two effects. Gutiérrez (2003) finds that for his sample of Latin American countries, competition (a zero-one variable) is associated with increased efficiency (lines per employee), while privatisation only appears to enhance investment when interacted with regulation, confirming the importance of both regulation and competition.

Lenain and Paltridge (2003) observe that the US Telecommunications Act of 1996 and the EU Telecommunications Directive of 1997 were indicative of a strong move to open fixed-line telecoms markets to competition. Thus while only 8 of 30 OECD countries had open competition in 1995, 22 had by 1998, and all but one (Turkey) had opened its markets by 2003 . New entrants have been successful in winning market share in long-distance and international markets, though they were less successful where access to the local loop is required, for example in broadband. In mobile telephony, almost all countries have three operators, although the fixed line incumbent often owns the largest mobile company. Mobile phone competition has frequently been sufficiently intense as to warrant little if any regulation, although increasingly mobile call termination is seen as an essential facility requiring regulation (Competition Commission, 2003).

The main regulatory issue is for what services competition is sufficiently advanced that ex ante regulation can be replaced by normal competition policy. New Zealand provides an interesting case study of the benefits and limitations of (very) light-handed regulation. De Boer and Evans (1996) estimate that productivity reduced costs annually at $5.6 \%$ from privatisation in 1987 to 1993 , and that prices fell, consumer surplus increased, and quality improved with deregulation, although it is hard to know what might have happened under more conventional ex ante regulation. Certainly the incumbent was able to contest and delay interconnection agreements with entrants, resulting in court cases and a Ministerial Inquiry into Telecommunications that reported in $2000{ }^{7}$ This led to a new telecommunications bill,

\footnotetext{
${ }^{6}$ The authors note that reverse causality might account for this association, in that low productivity encourages governments to accelerate privatisation (p129). They also note that the date of privatisation is taken as the first date of sale of any shares, not the date of transfer of control to private owners. See figure 1 for the importance of this distinction.

7 At http://www.teleinquiry.govt.nz/
} 
enacted in December 2001, that created a sector-specific regulator to regulate key services and accelerate dispute resolution (ITU, 2002).

Most developed countries are therefore converging on a structure that distinguishes sharply between services experiencing significant market power that require ex ante regulation, and potentially competitive services that can be left to normal competition legislation. Increasingly, cost-benefit tests are being used to guide changes in regulatory practice (as in the New Zealand inquiry cited above, and by Oftel in deciding on local loop unbundling for broadband, and more recently for regulating mobile phone termination charges, see Competition Commission, 2003). ${ }^{8}$

There are also important issues about whether sustainable (unregulated) competition is best ensured by facilities-based competition, or whether enforced unbundling or regulated access makes better use of the economies of scope between network and service, despite the extra cost of more intrusive regulation. Facilities-based competition, in which entrants provide new infrastructure (cable, mobile towers, etc), offers the prospect that the network (or large parts of it) ceases to be a natural monopoly requiring close regulation, but risks raising costs by duplication. This has been the preferred UK approach, where Oftel has been willing to accept some increase in total cost as the price to pay for more intense competition, with the prospect of more vigorous innovation and a swifter move to ending significant market power and asymmetric regulation. The US in contrast has attempted to enforce more access to network components, which has been contested in the courts and has arguably raised costs and retained inefficient forms of regulation.

The rapid evolution of the industry from regulated or state-owned incumbent to an increasingly competitive industry has been largely shaped by the rapid development of technology, and one should not underestimate the role of technical progress in precipitating structural and institutional change.

The conclusion on telecoms privatisation is that public ownership is now considered a handicap to innovation, rather than the natural source of investment funds, and it is therefore curious that state shareholdings are still significant in several Continental countries, as figure 1 shows.

Gas

In most countries, private quoted oil companies have been active in gas exploration and production, although some oil companies are state-owned, and there are specialised gas companies, the largest of which is the Russian Gazprom. The case for public ownership of gas exploration and production companies is relatively weak on commercial grounds, and has in the past normally been justified for energy policy reasons, specifically to ensure security of supply and for the government to gain access to strategically valuable information. BNOC (British National Oil Corporation) had been set up by the Labour Party in 1976 to develop

\footnotetext{
${ }^{8}$ While cost-benefit analysis is a desirable discipline, in the hands of advocates it can be distorted to favour the preferred solution, as argued extensively in the evidence presented to Competition Commission (2003) and the subsequent judicial review (Case CO/1192/03 High Court before Moses, J, 27 June 2003 at para 146).
} 
North Sea Oil, and was an obvious and early candidate for privatisation. The Conservative Manifesto of 1979 promised to review the case for continued public ownership. They decided to sell the company in 1982, after fierce opposition from the then opposition Labour party and with unfortunate timing after the price of oil suddenly fell (Lawson, 1992). At its height, BNOC only produced $7 \%$ of North Sea oil, the remainder coming from private or foreign companies, and the necessarily speculative nature of oil and gas exploration makes that part of the industry a poor fit with public ownership.

Gas production, certainly offshore production in the North Sea, is capital-intensive, and building a high pressure gas pipeline system is even more so. ${ }^{9}$ Where such developments have been undertaken by private oil and gas companies (as has been the norm outside the Soviet bloc), they have been financed on the back of long-term contracts, although in Britain the pipeline system was developed by the state-owned British Gas. Where the gas industry was publicly owned, the question was how best to restructure and regulate the industry, and where it was already in private ownership, the question was how best to (de-)regulate and liberalise the industry. The case for restructuring the industry is that the long-term contracts that were claimed to be essential to finance gas development and pipelines effectively vertically integrated the industry, often creating de facto monopolies, although they faced competition in final markets from other fuels, notably oil. As a result, and because there was no obvious international price for gas (unlike oil), gas was frequently either priced at oil parity, or markets were segmented, with gas for different uses effectively priced marginally below the cost of the competing fuel. This might be high-priced light fuel oil or electricity in domestic use, down to cheap coal for power generation. Such monopolistic pricing supported by vertical integration restricted the development of gas markets before deregulation, and created significant allocative inefficiencies.

Once the gas transmission and distribution network is mature, gas penetration high and the market developed, this equilibrium is vulnerable to regulatory opportunism, clearly demonstrated in the United States (Newbery, 2000). The US gas market is quantitatively and qualitatively different from that anywhere else in its maturity and market structure. Whereas Continental Europe was dominated by a small number of mainly state-owned enterprises, the US had over 8,000 producers, with the 40 largest accounting for $57 \%$ of 1990 gas production. They were connected to more than 1600 LDCs through 44 major interstate pipeline systems and hundreds of smaller pipeline companies (IEA, 1994). Despite the obvious prospect of competition in supply, from 1954 the Federal Power Commission had the power to regulate the well-head price of gas. The huge inefficiencies that resulted from the imposition of poorly designed regulation during the oil shocks was estimated to have cost consumers between $\$ 2.5$ and $\$ 5$ billion per year (Loury, 1981; Pierce, 1988; Ellig, 1991). Worse still, the resulting gas shortages caused by holding prices below market clearing levels encouraged merchant pipeline companies to sign long-term take-or-pay contracts at the height of the oil price boom without the precaution of linking prices to those of oil. As oil prices fell, these contracts became stranded at

\footnotetext{
${ }^{9}$ Gas delivered to Western Europe from Russia travels $6000 \mathrm{~km}$ from the wells through pipelines of $1200 \mathrm{~mm}$ diameter.
} 
above-market levels. Between 1972 and 1986 gas demand dropped by 20\%, creating excess capacity in pipeline networks, ideal conditions for the introduction of competition (IEA, 1994). Various Federal Energy Regulatory Commission orders from 1984 on finally unbundled and restructured the industry to one of third party access that facilitated active competition.

Unfortunately, that experience was not exploited when British Gas was privatised as a vertically integrated monopoly in 1986, although Vickers and Yarrow (1988, p267) criticised the failure to introduce competition. Under intense regulatory pressure, supported by the Office of Fair Trading and via references to the Monopolies and Mergers Commission, British Gas was persuaded to first functionally unbundle the competitive services from the natural monopoly networks, and then finally to break up the company into competitive and monopoly parts. The latter, Transco, in turn sold off storage activities and finally merged with the already unbundled electricity National Grid Company, consolidating the regulated energy networks in one company.

The British experience demonstrates that the natural monopoly pipes can be efficiently regulated, that investment can be sustained, and that the advantages of regulated third party access in creating a competitive spot and contract market have been substantial. The huge expansion of gas use in electricity generation has been matched by extensive exploration and development of increasingly hostile sectors in the North Sea, all under private ownership. Thus, in 1970, Western Europe consumed 73 million tonnes oil equivalent (Mtoe) of natural gas, only $13 \%$ as much as the US in that year. By 2000 , this figure had grown to 413 Mtoe, or nearly sixfold, to $70 \%$ of the US level. ${ }^{10}$

The case for liberalising gas has been extensively argued by the European Commission, but progress is handicapped by two significant obstacles. The first is that much of the industry is already in private ownership, so that the restructuring options readily available at privatisation are harder to secure, as Britain and the US demonstrate. The second is that the Continent is heavily and increasingly dependent on gas imports, mostly from politically unstable and distant countries, some of whom require transit rights through other unstable countries. Britain and the US are almost alone in being self-sufficient (at least at present) and having fully restructured their industries. Other countries see gas imports as of major geopolitical concern, and are most unlikely to allow the industry to evolve solely in response to market forces and short-term consumer demands. Nor is a competitive downstream industry necessarily the ideal complement to an upstream foreign monopoly as powerful as Gazprom.

Inevitably, then, importing countries are more concerned with energy policy and security of supply than securing the considerable potential benefits of greater gas-on-gas competition. Security is pursued by long-term contracts and geopolitical negotiations, combined with mandatory storage capacity. As Britain shifts from a gas exporter to gas importer within the next five years, these issues will increasingly have to be addressed by the British Government. Already the gas interconnector with the Continent has ended the period of gas pricing based on gas-on-gas competition, and re-established the link between gas prices and oil prices, thereby wiping out many of the benefits of earlier UK gas liberalisation.

\footnotetext{
${ }^{10}$ Data from BP Statistical Review of World Energy, 1980 and 2000
} 
The conclusion for gas is that regulated private ownership works well for the natural monopoly transmission and distribution system, but that creating a competitive gas market has been more difficult, particularly where gas is imported from few sources and/or from monopoly suppliers. Public ownership of production provides some comfort to countries concerned about controlling rent, although taxation and licence auctions work well in fiscally competent countries, at least where oil and gas interests have not suborned the political process. Public or municipal ownership in distribution may be somewhat less efficient than private regulated distribution companies. Municipalities are more likely to combine electricity and gas in one company, which may also be less efficient. ${ }^{11}$ In addition, municipal utilities are often tempted to use their franchise as a source of rent extraction to cross-subsidise other municipal services. The resulting extra deadweight costs may be no more serious than that caused by the irrationality of much of energy taxation (Newbery, 2003b), and smaller than the more substantial deadweight losses caused by the lack of competition in supply and the resulting under-utilisation of this lowcarbon energy resource.

\section{Electricity}

In terms of the criteria for successful privatisation and liberalisation, the electricity supply industry (ESI) presents a mixed picture. The evidence, reviewed below, is that the potential benefits from introducing competition by full ownership unbundling exceed any synergies of vertical integration in all but the smallest systems, and even there, the Single Buyer Model may be preferable to vertical integration. ${ }^{12}$ There is also evidence that well-designed pricecap regulation can enhance the performance of the unbundled network without prejudicing investment and quality of service, certainly in moderately independent systems like Britain (Pollitt and Domah, 2001). The main problem is the credibility of sustaining competitive wholesale generation markets when new investment is needed, and the difficulty of designing efficient markets and good regulation. There are important and largely unresolved issues to do with designing the interface between interconnected markets operating under different market rules, and there are serious concerns in Europe about the persistence of market power.

The ESI in most European countries worked technically quite well under the previous vertically integrated, largely state-owned structure. Electricity demand is fairly inelastic, so the inefficiencies of mis-pricing were small. It should not therefore be surprising that the gains from privatisation and restructuring appear modest even when the reforms were carefully done, as discussed below. It follows that imperfect restructuring could result in social losses, a lesson that was available before being underlined by the Californian electricity crisis of 2000 .

Just as technical progress has greatly aided the development of competition in telecoms, to the point of making the network natural monopolies contestable, so technical

\footnotetext{
${ }^{11}$ Stevenson (1982) compared 25 gas and electric utilities with 54 single fuel utilities (which therefore had to compete against the other fuel) and found the more competitive were less X-inefficient both statically (taking the capital stock as given) and dynamically (allowing for investment).

${ }^{12}$ The Single Buyer Model is one in which a single company, normally owning transmission, signs contracts with all generating companies and sells power to final consumers.
} 
progress in the ESI has reduced the barriers to entry into generation and supply. The development of combined cycle gas turbines (CCGT) makes this the natural choice for new generation, except where gas is not readily available, or local coal or hydro have overwhelming cost advantages. CCGT stations can enter rapidly (2 years) and at modest scale (50MW$500 \mathrm{MW})$, compared to coal and nuclear stations (5-10 years and $1000 \mathrm{MW})$. Gas in mature systems can be delivered closer to the final electricity market place more cheaply than electricity, reducing the need for expensive grid investments, and reducing the advantages of geography (well-placed coal mines or dams). CCGT technology therefore makes generation more contestable than before, and supports liberalisation.

These developments helped but did not dramatically change the case for liberalisation, which in Britain occurred before CCGT arrived. Generation stations in most of the larger industrialised countries are small compared to the market - the largest one in Britain (one of the largest in the world) had less than $8 \%$ of total capacity, and economies of scale of coal and nuclear stations fall off rapidly beyond $2 \%$ of total UK capacity. Smaller markets like Belgium are typically interconnected with a wider system, leaving only isolated small countries like Ireland facing a serious problem of indivisibility.

The quantitative evidence on reform experience is not extensive but is growing. Steiner (2001), and Hattori and Tsutsui (2003) examine the impact of regulatory reform on the ESI using panel data for 19 OECD countries, the latter study using a slightly longer time series (1987-99). The two studies reach different conclusions about the effect of creating a wholesale market on the industrial price of electricity, probably due to slightly different definitions of regulatory reform indicators. However, they both find that third party and retail access tend to lower industrial electricity prices and also lower the ratio of industrial to domestic prices, which in many countries represents an improvement in allocative efficiency. Steiner (2001) finds that privatisation improves operating efficiency and capacity utilisation.

Arocena and Waddams-Price (1999) find that in Spain public generators are on average more efficient than private generators under the earlier cost-of-service regulation. However, private generators catch up and overtake the public firms once cost-of-service regulation is replaced by price cap regulation, suggesting that private firms are more responsive to the kinds of market signals to be expected with liberalisation and good regulation.

UK electricity reform provides an excellent example of the benefits of restructuring and the importance of structural decisions. The UK tried all three possible models: in England and Wales the Central Electricity Generating Board (CEGB) was unbundled into three generating companies and the grid, the 12 distribution companies were privatised, and a wholesale market the Electricity Pool - created. After the three years of transitional contracts, consumer prices were set by free generation and (for larger customers) supply markets, combined with the regulated costs of transmission and distribution. Scotland retained the two incumbent vertically integrated companies with minimal restructuring and constrained export links to England. Northern Ireland adopted the Single Buyer model with the combined transmission/distribution company NIE holding long-term power purchase agreements (PPAs) with the three independent generating companies. 
Newbery and Pollitt (1997) and Pollitt (1997, 1998) have completed social cost benefit analyses of the three different models, with striking and intuitively plausible results. The restructuring of the CEGB immediately introduced daily competitive price bidding for each power station. All generating companies dramatically increased productivity and drove down costs, including the state-owned Nuclear Electric. The audit of the first five years was that the social benefits amounted to a reduction of costs of six per cent for ever compared to the counterfactual, equivalent to a $100 \%$ return on the sales price (when discounted at $6 \%$ real). These benefits were initially almost entirely captured by companies, for profits rose as costs fell and prices remained stubbornly high until continued and aggressive regulatory intervention forced extensive divestment of capacity. Figure 2 shows the gradual erosion of market shares of the two fossil generators, National Power and PowerGen, as they sold plant and Independent Power Producers (IPPs) entered.

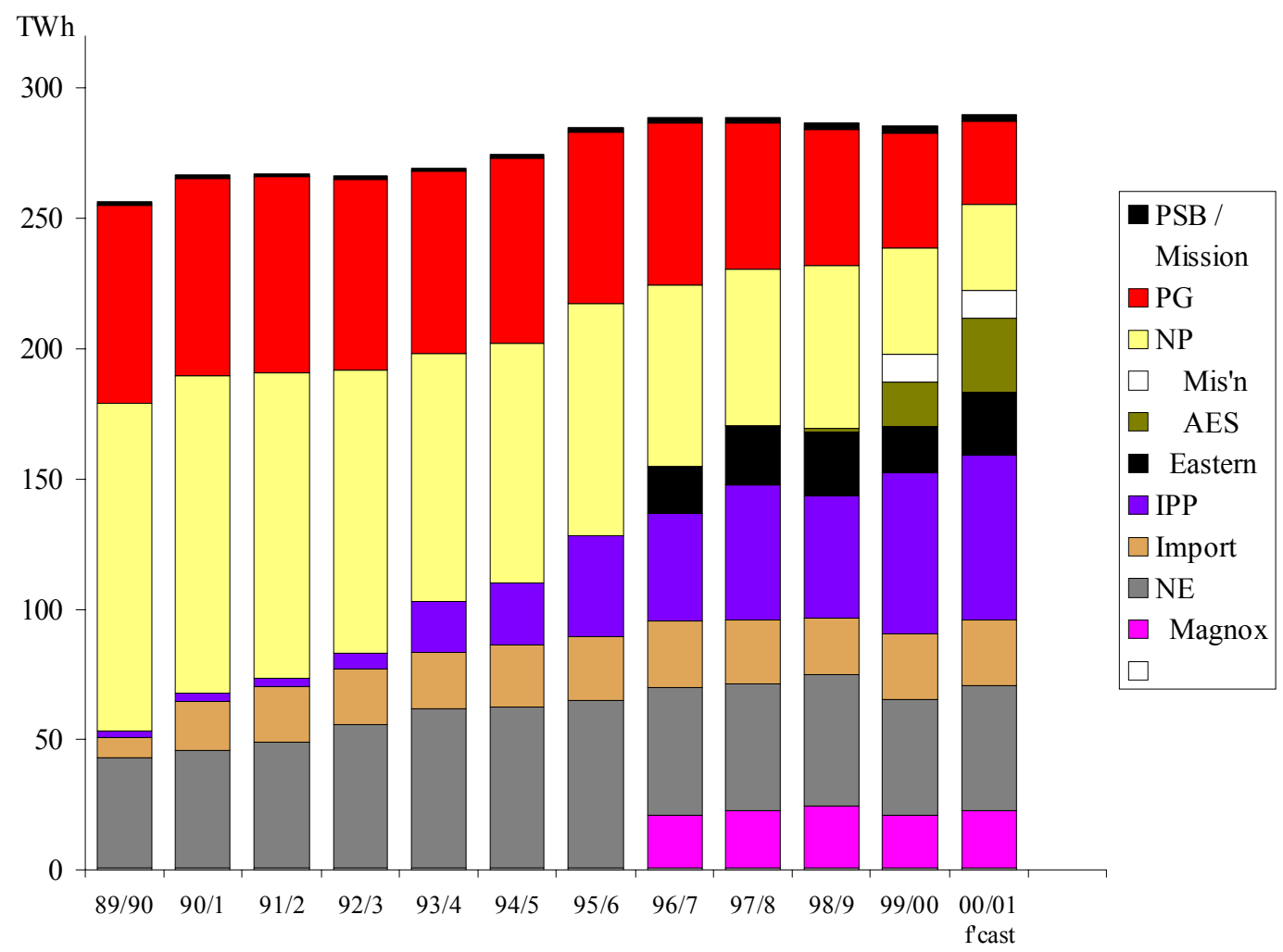

Figure 2 Output shares of generators in England and Wales

By the end of the decade the dominant duopoly had evolved into a relative unconcentrated industry with very competitive pricing. Entrants and incumbents operated efficient CCGT stations, a range of international generating companies bought divested plant, and the modern nuclear stations had been privatised.

Figure 3 shows the evolution of the wholesale electricity price. The cost of generating by coal and gas are also shown, so the margin of the price over the short-run avoidable fuel cost is readily seen. The prices are yearly moving averages of the half-hourly wholesale prices or the quarterly fuel prices, and are deflated by the Retail Price Index to the 2002 price level. The line with diamonds gives the Hirschman-Herfindahl Index (HHI), defined as the 
sum of the squared percentage shares of coal-fired plant capacity (which set the price most of the time until 1999) owned by different companies, read on the right-hand scale. An HHI of 5,000 represents a symmetric duopoly, and the initial concentration was somewhat higher than this as National Power was 50\% larger than PowerGen.

\section{Real electricity and fuel costs 1990-2003}

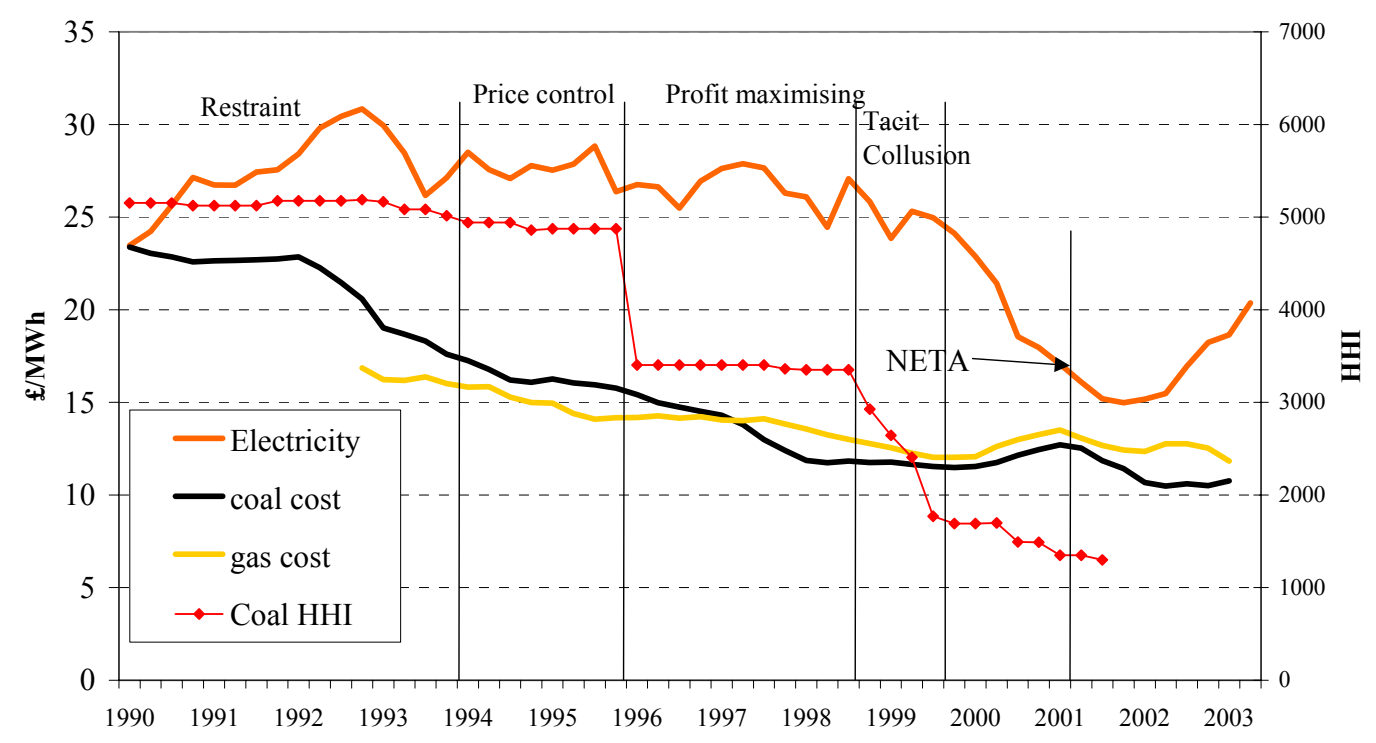

Figure 3 Evolution of wholesale prices in England and Wales

The detailed bidding behaviour of each generator is available and allows one to test for the exercise of market power. Sweeting (2001) shows that in the period up to 1994, the incumbents were bidding at less than the profit maximising level. Nevertheless, the widening price-cost margin led the regulator to impose a price control until plant were divested in 1996. The next period was characterised by individual profit maximisation, until further sales reduced concentration but not the price-cost margin. For a brief period until the market collapsed, generators were acting as though they were tacitly co-ordinating on a higher priced equilibrium. Once the market had fragmented sufficiently, this became unsustainable and prices collapsed, before the New Electricity trading Arrangements (NETA) were introduced in March 2001. The evidence therefore suggests that the industry must be relatively unconcentrated before the productivity gains are passed on in lower prices.

Scotland was a different story. In 1990 electricity prices were 10\% lower than in England, but the lack of competitive pressure meant that by the end of the decade prices were some $5 \%$ higher. The very modest benefits of privatisation were entirely absorbed by the costs of restructuring, delivering no net benefit. Northern Ireland gives a mixed picture. The long-term PPAs provided powerful incentives for increased plant availability and cost reductions, so that the improved generator performance outstripped that of the CEGB by three times. However, 
these PPAs retained the benefits with the generating companies. Consumers were only able to benefit by aggressive price reductions on the non-generating elements of cost, combined with Government subsidies to reduce the embarrassing price gap between Northern Ireland and Britain.

The lessons from UK electricity restructuring are clear. Increased competitive pressure on generation is needed to reduce costs and that requires separating generation from transmission and distribution. Whether these benefits will be passed on to consumers depends upon the intensity of competition - particularly the number of competitors and the existence of an open access wholesale market. Unrestructured industries, even if privatised, appear to deliver few benefits. Securing efficiency improvements in transmission and distribution requires tough regulatory price controls. Improvements in the first five years under the initial price controls were modest, with most of the price cuts, efficiency gains, and transfers to consumers confined to the second and subsequent regulatory reviews (Pollitt and Domah, 2001). The evidence suggests that regulators have to work hard to translate efficiency gains into lower consumer prices.

These economic lessons of liberalisation are reinforced by evidence from Norway and other EU countries (see e.g. Bergman et. al. 1999). Effective competition in generation under private ownership reduces costs and passes those cost reductions through to consumers in price reductions. Effective competition in generation requires regulated third party access to separately owned networks. This in turn requires ex ante regulation by specialised utility regulators, as competition law alone is inadequate given the special properties of electricity. For cost reductions to be passed through as price reductions there must be sufficiently many competing generating companies and a well-designed market for the various ancillary and balancing services, as well as adequate capacity. The number of actively competing generators may be increased by improving transmission links, as in the Nordic market (Bergman and von der Fehr, 1999). Otherwise, enforcing or encouraging divestiture of plant by the incumbent may be necessary. Contract coverage reduces market power and needs to be encouraged by the regulatory environment while entry barriers should be kept low. The lesson that unbundling is necessary has been taken to heart in restructuring choices around the world, and particularly in the European Union.

The European Commission presented its proposals for amending the Gas and Electricity Directives at the European Council in Stockholm in March 2001. ${ }^{13}$ The Commission pressed for vertical separation, preferably with legal separation of ownership, together with regulated third party access to transmission, a national regulator, and retail competition. Unfortunately, the Californian electricity crisis of December 2000 raised serious concerns that liberalisation could easily lead to supply insecurity, black-outs, and dramatic increases in prices, and slowed the subsequent progress towards agreeing a revised energy Directive (Newbery, 2003). This was finally accepted as 2003/54/EC and came into effect on August 4, 2003, in a somewhat attenuated form.

$13 \operatorname{COM}(2001) 125$ final, 13 March 2001; available together with the Press Release and Working Paper at http://europa.eu.int/comm/energy/en/internal-market/int-market.html 
It is probably too soon to tell whether privatising and restructuring the ESI will deliver sustainable improvements, but it is certainly early enough to say that poor market design and poor regulation can make matters considerably worse, as California demonstrates (Joskow and Kahn, 2002). Econometric studies can pick up the effects of reforms and restructuring on prices, investment and productivity, although the length of time since most reforms occurred is still rather short for the long-run effects to be clearly identified. Costbenefit studies can identify the net social gains from restructuring, but they are few and far between, as Pollitt (1997) notes, and are also restricted to a relatively short time period. ${ }^{14}$

The major concerns are that on the one hand, reforms have frequently failed to address issues of market power (Newbery, 2002b), and on the other hand competition may not be sustainable. There are concerns that the intensity of competition needed to transfer the efficiency gains and fuel price falls through to final consumers will reduce the incentive to invest, prejudicing security of supply. Surplus capacity, of the kind prevalent in Northern Europe, helped liberalisation by reducing the risks of shortage and attenuating market power, but generating companies benefit from a shortage of supply. Competition of the kind seen recently in the now very competitive English electricity wholesale market only just covers variable costs, which are only half total costs (Newbery and McDaniel, 2003). Generating companies may therefore delay investment and allow scarcity to increase, to allow prices to recover full costs, possibly erring on the side of too little rather than to much capacity. On the other hand, England and Wales demonstrates that if entry is easy and the market is both concentrated and as a result profitable, excess entry can also occur. Power cuts in the US, Italy and Denmark have raised doubts about investment adequacy and/or effective coordination in transmission. Although this may be a problem in some countries, Britain has invested $£ 16$ billion in transmission and distribution since privatisation in 1990 , or $100 \%$ of the turnover of the entire industry. Well regulated network companies can therefore deliver adequate infrastructure investment.

Looking around Europe, the ESI is still very much in a state of transition. Some countries have restructured and privatised: the UK is the leading example. Some have partially privatised, such as the Netherlands and Spain, some already had extensive private ownership, like Germany, but have extended the private share through mergers and acquisitions. Others are still in the process of restructuring, like Italy and Portugal, while France remains monolithically state-owned, and Scandinavia seems committed to the ownership status quo. In many countries, reforms have yet to be seen as obviously beneficial in reducing prices without prejudicing security of supply. Given the potentially small gains on offer and the considerable risks if the restructuring is flawed, and the difficulty of restructuring after privatisation, such caution is understandable.

\footnotetext{
${ }^{14}$ One problem is that typically a few years after restructuring, mergers and acquisitions change the corporate structure and make it increasingly difficult to reconstruct the aggregated "industry" accounts to compare with the counterfactual under continuing public ownership.
} 


\section{Water}

The typical problem facing publicly-owned European water companies is that they have inherited written-down assets of low book value that are in a poor condition to meet the increasingly onerous quality and environmental standards set by the European Commission. Prices that might be justified on the old book value are inadequate to finance the needed investment. On the face of it, this inability to finance activities at market rates of return would seem to be a serious impediment to privatisation, although the British experience demonstrates that it can be done. The assets were sold in 1989 for very small fraction of their modern equivalent asset value with an escalating price cap in place, of the form RPI-X+K. The $\mathrm{K}$ factor allows for a growing revenue stream to finance the borrowing needed for the ambitious investment programme.

Credibility of the regulatory framework in Britain was reinforced by the previous experience of other privatisations, and because the evident need for continued recourse to the capital market would keep the regulator honest. The first Director General, Ian Byatt, already had a strong reputation for cost-benefit analysis and proper public sector accounting. He commissioned and published a series of papers on the proper measurement of the cost of capital (which can be found on the Ofwat web-site). The importance of incentives for efficiency and quality were recognised explicitly in the Water Industry Act 1991. The Act anticipates that each water or water and sewerage company will be benchmarked against its peers. To be effective this requires a sufficient number of independent companies and the Act requires all mergers within the sector above a certain size to be referred to the Competition Commission. They will balance the efficiency gains of the merger (and the consequential reduction in water bills) against the reduction in regulatory information caused by the loss of a comparator. Such price-cap regulation has proven effective in driving down costs and improving productivity, at least (as with other utilities) after the first post-privatisation periodic review (Saal and Parker, 2003).

Water differs from the utilities mentioned so far in that it is costly and difficult to create competition, both because water has low value/weight and is costly to move across regional boundaries (which were set to coincide with water cachement areas), and because of the difficulty of ensuring quality. Competition is therefore unlikely to be an effective source of efficiency gains, and the case for privatisation rests almost entirely on better management in the private sector (through the stock market discipline of take-overs), and on the improvement in regulation made possible by creating an independent regulator.

The downside of British water privatisation is that the Government no longer has such a stake in resisting increasingly unreasonable EU Directives on water quality, few of which would pass any social cost-benefit test. The companies have also become free to speculate in businesses in which they were soon shown to have negligible expertise (hotels being a notable example). The pressure on public owners to ensure that water quality is adequate is likely to be strong, if there is any evidence of serious health risks. The advantage of minimising the cost of delivering potable water by placing it under local authority control, with many other claims on its finance, is appealing, at least to economists. The case for water privatisation is therefore weaker than for most other utilities. 


\section{Rail}

Railway passenger transport is uncompetitive with road (and probably air over longer distances) except in dense urban areas, which includes delivering passengers to those urban areas, and where the infrastructure costs have been largely written off. Freight traffic is marginal except for dedicated loads over moderate to long distances, such as coal and aggregates, where speed is not critical and dedicated rolling stock and handling facilities can be installed. Rail can be made to appear more competitive with road by under-investing in road and raising the price of road travel through otherwise unwarrantably high road charges and taxes. Commuter travel may be socially desirable by rail, but the economics of very peaky demands are commercially unattractive. As a result, all European railways require heavy subsidies. The ratio of revenues to costs varies from $9 \%$ in Hungary to $66 \%$ in Finland, with Britain at $57 \%$, compared to the average over 16 European countries of $39 \%$ (Nash et al, 2002).

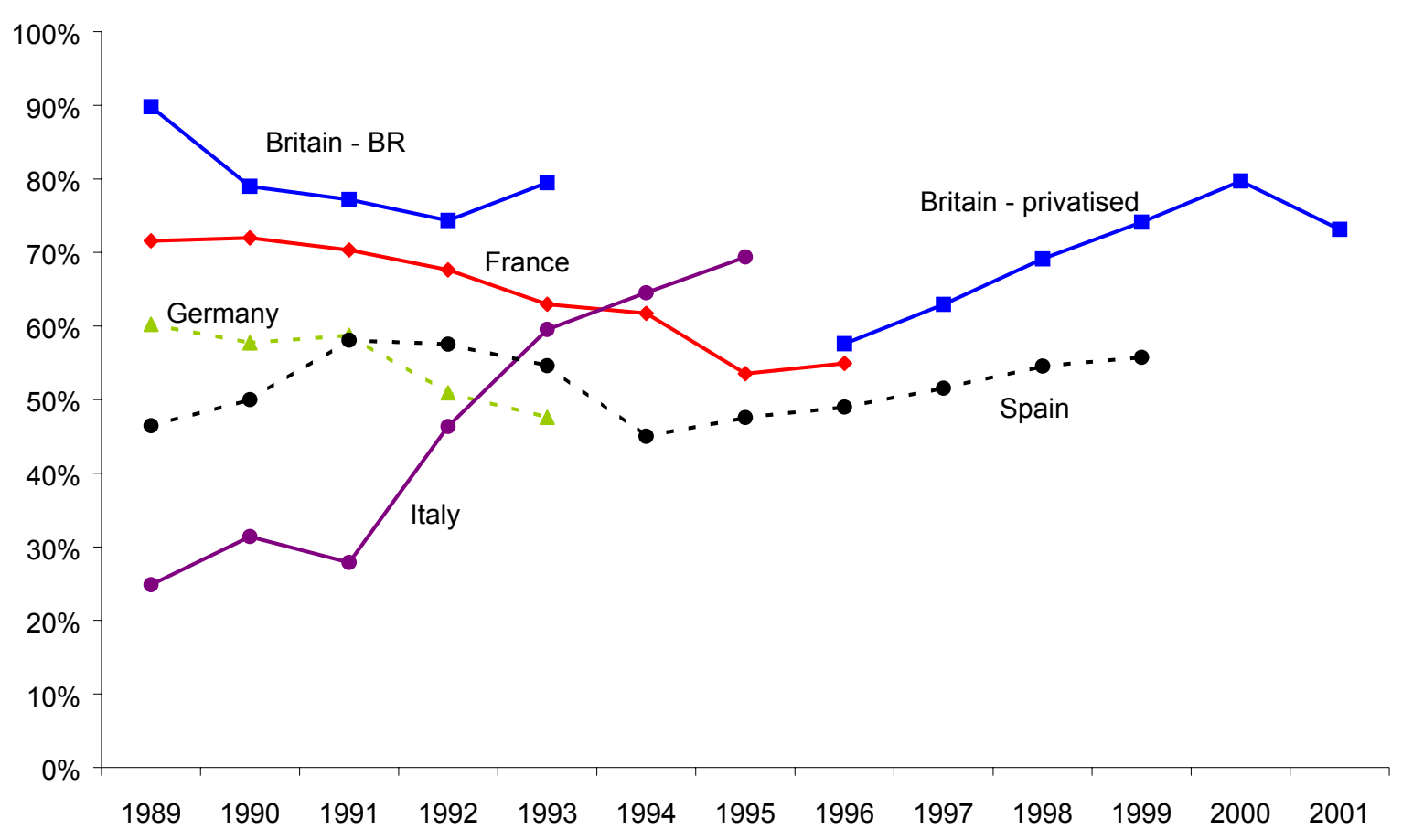

Figure 4 Cost recovery ratio European Railways (1989-2001)

The first and arguably fatal problem with privatising European railways is railway's failure to cover even operating costs (including maintaining the system), and the consequential need for continuing subsidy. Figure 4, taken from Smith (2003), shows the cost recovery ratio (the ratio of non-subsidy revenue to total costs) for various European railways, showing that all railways needed subsidies, and although Britain appears to need the lowest subsidies, these increased after privatisation. There are two solutions available: keep the loss-making part in public ownership, or feed subsidies into the industry. The first solution, exemplified by Sweden, keeps the rail infrastructure in public ownership and makes it available at marginal cost. Private companies can then use the track (just as roads are state-financed but road transport is privately provided). Subsidies may still be required for rail users. The second solution was adopted in 
Britain, where the entire industry was privatised. Railtrack charges the full cost (typically by a two-part tariff) and the track users are subsidised directly, originally via the franchise office, OPRAF. Railtrack's charges were regulated by the Office of Rail Regulation, ORR.

The tension intrinsic in this second solution is considerable. Around the time of Railtrack privatisation, the Train Operating Companies or TOCs bid the amount they would need to run the franchises, and the British Government was willing to underwrite these declining subsidies, in part compensated by the sales revenue from Railtrack, and in part replacing existing annual Treasury subventions. Indeed, over the first five years, the total cost to the Government appears to have fallen compared to the counterfactual (assuming the same increase in passenger demand, Pollitt and Smith, 2002). The problem arises when franchises are re-tendered, when the periodic review increases the charges, or between periodic reviews when the rail regulator increases charges to reflect inescapable and unexpected changes in costs, particularly those visited upon the industry by the Health and Safety Executive, for example after any rail crash. Clearly, these cannot be passed to the TOCs in full to be recovered from passengers, as only some fares are capped and the remaining fares are already set at profit maximising levels, given the competition from road.

The Government is particularly unenthusiastic about granting an independent regulator the power to force the Government to increase payments via OPRAF or its successor, the Strategic Rail Authority, SRA. The fight over who pays for such cost increases is likely to end in tears, particularly if there are dispersed private shareholders, as was the case with Railtrack. These tensions are made worse when naturally optimistic engineers committed to railway excellence underestimate the costs of enhancements (as they always do). Railtrack was effectively forced into bankruptcy when a minor rail accident at Hatfield revealed a large shortfall in the required annual maintenance expenditure, and the full cost of the West Coast Main Line became clearer. That cost had escalated from its original (and presumably wildly optimistic) estimate of $£ 2.5$ billion to over $£ 12$ billion (against a sales price for Railtrack of less than $£ 3$ billion).

Many of these problems would arise when running an existing railway at preprivatisation levels of demand and with existing capacity. The problems were greatly amplified by the unexpected $30 \%$ increase in demand, reversing 50 years of stable or declining rail use and immediately exposing the capacity constraints on the existing system. A regulated utility like Railtrack may be well-designed to manage existing assets under a traditional price-cap regulatory regime, but not be well-suited for managing investments of highly uncertain cost, much of which has extremely dubious benefit-cost ratios.

In the case of the water companies, the existing assets were sold for less than $10 \%$ of their replacement value, and the Regulatory Asset Base was similarly low relative to future investment needs. However, those investment expenditures were reasonably predictable, relatively standardised, and could be protected though the K-factor which allowed the costs to be recovered from consumers over the succeeding periodic reviews in a sufficiently predictable way that banks could provide bridging finance. None of these benign characteristics holds in the case of railways. Passengers cannot pay the increased cost, long-term guarantees from the Government are essentially worthless, the benefit-cost ratios are doubtful, and therefore 
vulnerable to subsequent close scrutiny by an intelligent Department of Transport, so only the most optimistic engineering-oriented management would consider undertaking such investments.

The present structure of the British railway industry has been criticised for excessive vertical unbundling. Much of the criticism has been directed to the separation of track from train operation. When new investment is less critical, and the number of competing or co-using companies is manageable, the separation of train from track is not necessarily the wrong solution. Provided, and this is a considerable proviso, that the true costs imposed on track by different trains can be properly identified and correctly charged, separation should not reduce the synergies of vertical integration too much. This is important, as under the EC Railway Directive, train operations should be separated from the track to facilitate equal access by different train companies to facilitate efficient inter-country use on the Continent.

The major restructuring failure appears to have been the separation of track from maintenance, and the casualisation of the maintenance workforce attendant upon that separation. It may be that this problem could have been overcome once a proper asset register and methods of measuring quality have been put in place, combined with sufficiently well-funded and longlived maintenance companies to provide the necessarily lifetime guarantees for work done. The old BR system had dedicated and experienced maintenance engineers responsible for sections of track with which they became very familiar. This represented a decentralised form of asset register in their knowledge base enabling timely maintenance. Railtrack has now been effectively absorbed back into the public sector as Network Rail, under an awkward and probably unsustainable ownership, regulatory and financing structure. Track maintenance activities were taken back into the core network company in October 2003, with the expectation of cutting annual maintenance costs from $£ 1.3$ billion to $£ 1$ billion. That would seem to confirm the importance of economies of scope between operation and maintenance for railways.

It remains to be seen whether privatising parts or the whole of railway industries is a viable and preferable alternative to the very expensive public ownership common in most countries. If it reduces cost (probably by also reducing the network size) then it might be worthwhile. If, as in Britain, it raises the cost of making explicit and legalistic the safety regulations (as with water), and if unbundling loses economies of scope without reducing costs adequately, then the privatisation experiment may prove costly.

\section{Perceptions of privatisation}

As a general rule of thumb, privatisation is popular provided prices appear to come down and/or the quality of service improves. Privatisation is unpopular with unions when associated with job losses or with a fragmentation of union power. High profits, and even more, high pay to the directors, attract unfavourable media coverage, although probably have little effect by themselves unless associated with other unsatisfactory events, such as water rationing caused by drought, power black-outs, or price rises. In Britain, telecoms privatisation ended the waiting list for connection, and service quality improved. Long distance and international calls became dramatically cheaper, and the rebalancing of tariffs only adversely affected a small fraction of the population. Waddams Price and Hancock (1998) estimated that average real domestic 
telephone bills decreased by $£ 73$ from 1984 to 1997, but pensioners lost about $£ 10$ and about $1 \%$ of the population are deterred from having a fixed line because of the higher rental cost.

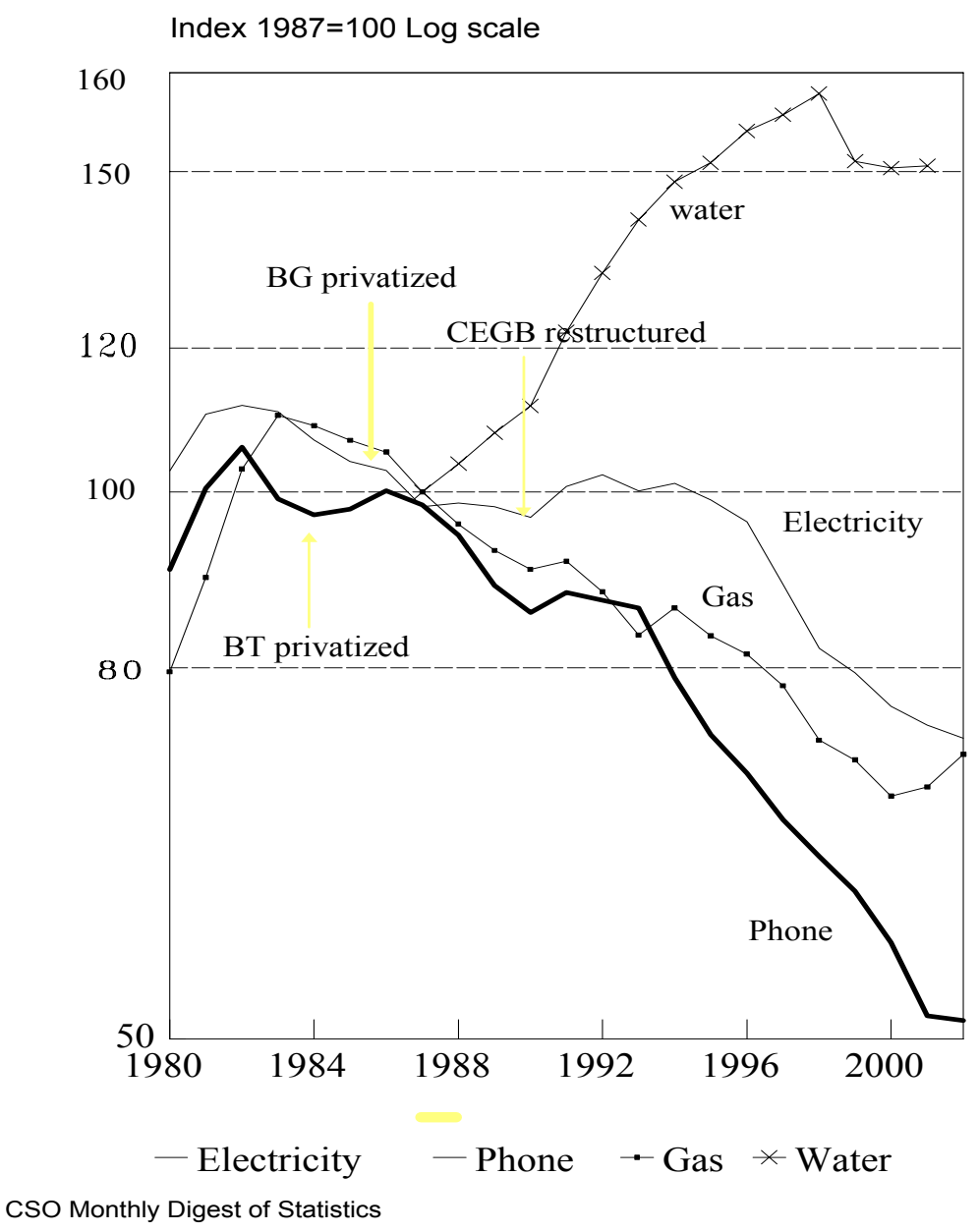

Figure 5 Real domestic price of public utilities for UK

Figure 5 shows the evolution of real domestic prices for gas, electricity, water (after 1987 ) and telephones, plotted on a log scale so that equal proportional changes in prices are represented by the same vertical distances. ${ }^{15}$ Gas prices fell steadily until 2000, when Britain connected to the Continental gas grid and their oil-linked prices. In electricity, fuel costs fell and so (eventually) did real final domestic prices. Even though domestic prices failed to fall (except for those switching) with the 2000-2002 wholesale price fall of $40 \%$, because prices did not go up and consumers could switch, there was remarkably little criticism of the retailers. In water, because prices rose with no obvious change in the service, the privatisation was relatively unpopular. Railway privatisation has been even more severely criticised than it perhaps merited, but there is a long tradition of complaining about inadequate and unreliable railway services, and no great conviction that matters would be much better under public ownership. Certainly, the quasi-privatisation of track operations of London Underground was strongly criticised before it

15 That is, the index of consumer prices in the ONS Monthly Digest of Statistics are deflated by the Retail Price Index. 
happened, but if, as planned, quality improves, and the cost is ultimately borne by taxpayers, opposition will probably be muted.

In Eastern Europe, privatising electricity and gas required large increases in domestic tariffs, which were understandably unpopular, and often resisted by changed governments, to the detriment of regulatory credibility. The main lesson to draw is that how privatisation is perceived has a rather tenuous relationship with whether the privatisation is judged an economic success, as other costs (such as fuel inputs, or environmental requirements) may overwhelm any efficiency gains in affecting the final price that is the prime determinant of popularity.

\section{Lessons learned}

The main lesson to draw is that the difficulty of meeting the various criteria for successful privatisation varies across industries. In telecoms, privatisation is almost certainly better than public ownership, but poorly designed privatisation is costly compared to a delay followed by a more carefully designed privatisation. In gas, the main problem is one of moving the industry towards a more satisfactory market structure, and liberalisation may only be able to play a modest role if the industry is already largely private. Electricity, on the other hand, was largely publicly owned in Europe, and offered important opportunities to move to a better industrial structure - an opportunity that was often wasted. The gains from electricity privatisation are modest, and the risks of costly choices considerable. In water, the case for privatisation is weaker as liberalisation is difficult, and regulation less effective at resisting unreasonable quality standards. Finally, it is even more difficult to privatise railways in a way that both improves performance and reduces the public cost. 


\section{References}

Armstrong, M. 1996, Network Interconnection, DPET 9625, Southampton

Armstrong, M. (1998), 'Network Interconnection in Telecommunications', Economic Journal, 108 May, 545-564

Armstrong, M., S. Cowan and J. Vickers, (1994) Regulatory Reform - Economic Analysis and British Experience, Cambridge: MIT Press.

Arocena, P. and C. Waddams-Price (1999). "Generating Efficiency: Economic and Environmental Regulation of Public and Private Electricity Generators in Spain", mimeo

Averch, H. and L. L. Johnson (1962). "Behavior of The Firm Under Regulatory Constraint", American Economic Review, No. 52, pp. 1053-1069.

Bartle, I. (ed.) (2003) The UK Model of Utility Regulation: A $20^{\text {th }}$ anniversary collection to mark the 'Littlechild Report' - retrospect and prospect, Bath: Centre for the study of Regulated Industries

Bell, A. (1995) 'The Telecommunications Industry 1994/95', ch 5, pp 93-104 in CRI Regulatory Review 1995, ed. P. Vass, London: CIPFA

Bergara, Mario, Witold J. Henisz and Pablo T. Spiller (1997). "Political Institutional and Electric Utility Investment: A Cross-Nation Analysis", POWER Working Paper No. PWP-052, University of California Energy Institute, University of California at Berkeley.

Bergman, L., G Brunekreeft, C. Doyle, B-H von der Fehr, D M Newbery, M Pollitt, and P Regibeau, (1999), A European Market for Electricity? London: Centre for Economic Policy Research.

Bergman, L and N-H von der Fehr (1999) 'The Nordic Experience: diluting market power by integrating markets' ch. 7 in Bergman et. al. (1999)

Boylaud, O. and G. Nicoletti, (2001), 'Regulation, Market Structure and Performance in Telecommunications', OECD Economic Studies. 32: 99-142

Competition Commission, (2003) Mobile phone charges inquiry, London: Competition Commission

Crandall, R.W. and L. Waverman (1997) Universal Service: For Whom the Bell Used to Toll, Washington DC: Brookings Institution.

Cremer, H., M. Marchand and J.Thisse, (1989) 'The public firm as an instrument for regulating an oligopolistic market', Oxford Economic Papers, 41, April 283-301.

de Boer, D.B. and L. Evans (1996), 'The Economic Efficiency of Telecommunications in a Deregulated Market: The Case of New Zealand', Economic Record, 72(216): 24-35

Ellig, J. (1991) 'Endogenous Change and the Economic Theory of Regulation', Journal of Regulatory Economics, vol. 3 no. 3, 265-75.

Galal, A. Jones, L. Tandon, P. and Vogelsang, I. (1994), Welfare Consequences of Selling Public Enterprises: An Empirical Analysis, Oxford University Press.

Gilbert, R. J and D.M. Newbery, (1994) 'The dynamic efficiency of regulatory constitutions', The Rand Journal, 25(4), 538-54.

Green, R. and T. McDaniel (1998), Competition in electricity supply: will "1998" be worth it? Fiscal Studies vol 19.

Gutiérrez, L. F. (2003), "The Effect of Endogenous Regulation on Telecommunications Expansion and Efficiency in Latin America", Journal of Regulatory Economics, V. 23, No. 3, pp. 257286.

Hausman, J.A. (1997) 'Valuing the effect of regulation on new services in telecommunications', Brookings Papers: Microeconomics, 1-38

Hausman, J.A, T. Tardiff, and A. Belinfante, (1993), 'The Effects of the Breakup of AT\&T on Telephone Penetration in the United States', American Economic Review, 83(2), May, 178-84.

Hattori, Toru and Miki Tsutsui (2003). "Economic Impact of Regulatory Reforms in the Electricity Supply Industry: A Panel Data Analysis for OECD Countries", Energy Policy, article in press

IEA (1994) Natural Gas Transportation: Organisation and Regulation, IEA/OECD, Paris.

ITU (2002) Trends in Telecommunications Reform 2002: Effective Regulation. Geneva: International Telecommunications Union

Joskow, P. and E. Kahn (2002), 'A quantitative analysis of pricing behavior in California's wholesale electricity market during summer 2000', Energy Journal, Dec, pp1-35. 
Kornai, J. (1992) 'The Post-Socialist Transition and the State: Reflections in the Light of Hungarian Fiscal Problems', AER Papers and Proc. 82(2), May, 1-21

Laffont, J-J, P. Rey and J. Tirole, 1998a, 'Network Competition: Overview and Non-discriminatory Pricing', Rand Journal of Economics 29(1):1-37

Laffont, J-J, P. Rey and J. Tirole, 1998b, 'Network Competition: Price Discrimination', Rand Journal of Economics 29(1):38-56

Lawson, N (1992) The view from No. 11: Memoirs of a Tory Radical, London: Bantam

Lenain, P. and S. Paltridge (2003) 'After the telecommunications bubble', Paris: OECD ECO/WKP(2003)15, at http://www/oecd.org/eco

Lipton, M. and C. Simkins (eds.) (1993) State Owned Market in Post Apartheid South Africa, Johannesburg: Witwatersrand University Press.

Littlechild, S. (1983) Regulation of British Telecommunications profitability, London, HMSO, reprinted in Bartle (2003)

Lowry, E.D. (1973) 'Justifications of regulation: The case for natural monopoly', Public Utilities Fortnightly, Nov. 8, 1-7.

Martin, S. and D. Parker (1987) The impact of privatisation: ownership and corporate performance in the UK, London: Routledge

Mason, R. (1998) 'Internet telephony and the international accounting rate system', Telecommunications Policy, 22(11), 931-44.

Nash C., P. Bickel, R. Friedrich, H. Link and L. Stewart (2002) 'The Environmental Impact of Transport Subsidies', Paper presented at the OECD conference on environmentally harmful subsidies. Paris: OECD.

Newbery, D. M. (1997) 'Privatisation and Liberalisation of Network Utilities', European Economic Review, 41(3-5), 357-84

Newbery, D. M. (1998) 'The Regulator's Review of the English Electricity Pool', Utilities Policy, 7(3), 129-41

Newbery, D.M. (2000), Privatization, Restructuring and Regulation of Network Utilities, Cambridge, MA: MIT Press.

Newbery, D.M. (2002a), 'Regulating unbundled network utilities', Economic and Social Review, 33(1), 23-43.

Newbery, D.M. (2002b), 'Problems of liberalising the energy utilities', European Economic Review, $46,919-27$.

Newbery, D.M. (2003a) 'Regulatory challenges to European electricity liberalisation' Swedish Economic Policy Review, 9(2), Fall, 9-44.

Newbery, D.M. (2003b) 'Sectoral dimensions of sustainable development: energy and transport', Economic Survey of Europe 2003 No. 2

Newbery, D.M. and M.G. Pollitt (1997) 'The Restructuring and Privatisation of the CEGB- Was it worth it', Journal of Industrial Economics, XLV (3), 269-303

Newbery, D.M. and T. McDaniel (2003) 'Auctions and Trading In Energy Markets - An Economic Analysis', Ch 12, CRI Regulatory Review 2003

OJ (2001), Proposal for a Regulation of the European Parliament and of the Council on conditions for access to the network for cross-border exchanges in electricity. Official Journal C 240 E, 28/08/2001, p 72-8.

OJ (2002), Opinion of the Economic and Social Committee. Official Journal C 36 E, 08/02/2002, p $10-19$.

Parker, D (2003) “The UK's privatisation experiment: the passage of time permits a sober assessment", this volume, ppXX-YY.

Pierce, R.J. (1988) 'Reconstituting the Natural Gas Industry from Well Head to Burnertip', Energy Law Journal 9, 11-57.

Pollitt, M.G. (1997), 'The impact of liberalisation on the performance of the electricity supply industry: an international survey.' Journal of Energy Literature, Vol.3, No.2, pp.3-31.

Pollitt, M.G. and Domah, P.D. (2001), 'The Restructuring and Privatisation of the Regional Electricity Companies in England and Wales: A social cost benefit analysis', Fiscal Studies, Vol.22, No.1, pp.107-146. 
Pollitt, M.G. and Smith, A.J. (2002) 'The Restructuring and Privatisation of British Rail: Was it really that bad?', Fiscal Studies, Vol.23, No.4, pp.463-502

Roller, L-H and Waverman, L. (2001) 'Telecommunications Infrastructure and Economic Development: A Simultaneous Approach', American Economic Review. 91(4): 909-23.

Saal, D.S. and D Parker (2003) 'The impact of privatisation on productivity growth in the English and Welsh Water and Sewerage Industry', CESifo Conference paper, January

Sappington, D.E. and J.E. Stiglitz (1987) 'Privatization, Information and Incentives'. J. of Policy Analysis and Management, 6(4), 567-81.

Schneider, V. and A. Jaeger, (2003) 'The privatization of infrastructure in the theory of the state: an empirical overview with a discussion of competing theoretical explanations', ch 4 pp101-40 in On creating competition and strategic restructuring, E.F.M. Wubben and W. Hulsink (eds.) Northampton, MA: Edward Elgar

Smith, A.J.S. (2003) "Developments in financing Britain's Railways: perspectives from recent experience and comparisons with other European models" mimeo, Cambridge University Judge Institute

Steiner, Faye (2001). "Regulation, Industry Structure and Performance in the Electricity Supply Industry", OECD Economic Studies No. 32, 2001/I.

Stevenson, R.E. (1982) 'X-Inefficiency and Interfirm Rivalry: Evidence from the Electric Utility Industry', Land Economics; 58, Feb. 52-66.

Sweeting, A. (2001) 'The effect of falling market concentration on prices, generator behaviour and productive efficiency in the England and Wales electricity market', MIT Department of Economics.

Vickers, J. and G. Yarrow (1988) Privatization: An economic analysis, Cambridge: MIT Press

Vogelsang, I. (2003) "Price regulation of access to telecommunications networks", Journal of Economic Literature, XLI, 830-62.

Waddams Price, C. and R. Hancock (1998) 'Distributional effects of liberalizing residential utility markets in the UK', Fiscal Studies, 19(3)

Zelner, B. A. and W. J. Henisz (2000). "Political Institutions, Interest Group Competition and Infrastructure Investment in the Electric Utility Industry: A Cross-National Study", Working Paper WP 00-03, Reginald H. Jones Center, The Wharton School, University of Pennsylvania.

Wallsten, Scott (2002), "Does Sequencing Matter? Regulation and Privatization in Telecommunications Reforms", mimeo, February 2002.

Willner, J. (2003) 'Public ownership and privatisation in Finland', CESifo Conference paper, January

Wellenius, B and P.A. Stern (1994) Implementing Reforms in the Telecommunications Sector, Washington DC: World Bank

WTO, (1998) Data on Telecommunications markets covered by WTO Negotiations on Basic Telecommunications; (at URL http://www.wto.org/press/data3.htm) 


\section{CESifo Working Paper Series}

(for full list see www.cesifo.de)

1066 Christian Keuschnigg, Public Policy and Venture Capital Backed Innovation, October 2003

1067 Thomas von Ungern-Sternberg, State Intervention on the Market for Natural Damage Insurance in Europe, October 2003

1068 Mark V. Pauly, Time, Risk, Precommitment, and Adverse Selection in Competitive Insurance Markets, October 2003

1069 Wolfgang Ochel, Decentralising Wage Bargaining in Germany - A Way to Increase Employment?, November 2003

1070 Jay Pil Choi, Patent Pools and Cross-Licensing in the Shadow of Patent Litigation, November 2003

1071 Martin Peitz and Patrick Waelbroeck, Piracy of Digital Products: A Critical Review of the Economics Literature, November 2003

1072 George Economides, Jim Malley, Apostolis Philippopoulos, and Ulrich Woitek, Electoral Uncertainty, Fiscal Policies \& Growth: Theory and Evidence from Germany, the UK and the US, November 2003

1073 Robert S. Chirinko and Julie Ann Elston, Finance, Control, and Profitability: The Influence of German Banks, November 2003

1074 Wolfgang Eggert and Martin Kolmar, The Taxation of Financial Capital under Asymmetric Information and the Tax-Competition Paradox, November 2003

1075 Amihai Glazer, Vesa Kanniainen, and Panu Poutvaara, Income Taxes, Property Values, and Migration, November 2003

1076 Jonas Agell, Why are Small Firms Different? Managers' Views, November 2003

1077 Rafael Lalive, Social Interactions in Unemployment, November 2003

1078 Jean Pisani-Ferry, The Surprising French Employment Performance: What Lessons?, November 2003

1079 Josef Falkinger, Attention, Economies, November 2003

1080 Andreas Haufler and Michael Pflüger, Market Structure and the Taxation of International Trade, November 2003

1081 Jonas Agell and Helge Bennmarker, Endogenous Wage Rigidity, November 2003 
1082 Fwu-Ranq Chang, On the Elasticities of Harvesting Rules, November 2003

1083 Lars P. Feld and Gebhard Kirchgässner, The Role of Direct Democracy in the European Union, November 2003

1084 Helge Berger, Jakob de Haan and Robert Inklaar, Restructuring the ECB, November 2003

1085 Lorenzo Forni and Raffaela Giordano, Employment in the Public Sector, November 2003

1086 Ann-Sofie Kolm and Birthe Larsen, Wages, Unemployment, and the Underground Economy, November 2003

1087 Lars P. Feld, Gebhard Kirchgässner, and Christoph A. Schaltegger, Decentralized Taxation and the Size of Government: Evidence from Swiss State and Local Governments, November 2003

1088 Arno Riedl and Frans van Winden, Input Versus Output Taxation in an Experimental International Economy, November 2003

1089 Nikolas Müller-Plantenberg, Japan’s Imbalance of Payments, November 2003

1090 Jan K. Brueckner, Transport Subsidies, System Choice, and Urban Sprawl, November 2003

1091 Herwig Immervoll and Cathal O'Donoghue, Employment Transitions in 13 European Countries. Levels, Distributions and Determining Factors of Net Replacement Rates, November 2003

1092 Nabil I. Al-Najjar, Luca Anderlini \& Leonardo Felli, Undescribable Events, November 2003

1093 Jakob de Haan, Helge Berger and David-Jan Jansen, The End of the Stability and Growth Pact?, December 2003

1094 Christian Keuschnigg and Soren Bo Nielsen, Taxes and Venture Capital Support, December 2003

1095 Josse Delfgaauw and Robert Dur, From Public Monopsony to Competitive Market. More Efficiency but Higher Prices, December 2003

1096 Clemens Fuest and Thomas Hemmelgarn, Corporate Tax Policy, Foreign Firm Ownership and Thin Capitalization, December 2003

1097 Laszlo Goerke, Tax Progressivity and Tax Evasion, December 2003

1098 Luis H. B. Braido, Insurance and Incentives in Sharecropping, December 2003 
1099 Josse Delfgaauw and Robert Dur, Signaling and Screening of Workers' Motivation, December 2003

1100 Ilko Naaborg, Bert Scholtens, Jakob de Haan, Hanneke Bol and Ralph de Haas, How Important are Foreign Banks in the Financial Development of European Transition Countries?, December 2003

1101 Lawrence M. Kahn, Sports League Expansion and Economic Efficiency: Monopoly Can Enhance Consumer Welfare, December 2003

1102 Laszlo Goerke and Wolfgang Eggert, Fiscal Policy, Economic Integration and Unemployment, December 2003

1103 Nzinga Broussard, Ralph Chami and Gregory D. Hess, (Why) Do Self-Employed Parents Have More Children?, December 2003

1104 Christian Schultz, Information, Polarization and Delegation in Democracy, December 2003

1105 Daniel Haile, Abdolkarim Sadrieh and Harrie A. A. Verbon, Self-Serving Dictators and Economic Growth, December 2003

1106 Panu Poutvaara and Tuomas Takalo, Candidate Quality, December 2003

1107 Peter Friedrich, Joanna Gwiazda and Chang Woon Nam, Development of Local Public Finance in Europe, December 2003

1108 Silke Uebelmesser, Harmonisation of Old-Age Security Within the European Union, December 2003

1109 Stephen Nickell, Employment and Taxes, December 2003

1110 Stephan Sauer and Jan-Egbert Sturm, Using Taylor Rules to Understand ECB Monetary Policy, December 2003

1111 Sascha O. Becker and Mathias Hoffmann, Intra-and International Risk-Sharing in the Short Run and the Long Run, December 2003

1112 George W. Evans and Seppo Honkapohja, The E-Correspondence Principle, January 2004

1113 Volker Nitsch, Have a Break, Have a ... National Currency: When Do Monetary Unions Fall Apart?, January 2004

1114 Panu Poutvaara, Educating Europe, January 2004

1115 Torsten Persson, Gerard Roland, and Guido Tabellini, How Do Electoral Rules Shape Party Structures, Government Coalitions, and Economic Policies? January 2004

1116 Florian Baumann, Volker Meier, and Martin Werding, Transferable Ageing Provisions in Individual Health Insurance Contracts, January 2004 
1117 Gianmarco I.P. Ottaviano and Giovanni Peri, The Economic Value of Cultural Diversity: Evidence from US Cities, January 2004

1118 Thorvaldur Gylfason, Monetary and Fiscal Management, Finance, and Growth, January 2004

1119 Hans Degryse and Steven Ongena, The Impact of Competition on Bank Orientation and Specialization, January 2004

1120 Piotr Wdowinski, Determinants of Country Beta Risk in Poland, January 2004

1121 Margarita Katsimi and Thomas Moutos, Inequality and Redistribution via the Public Provision of Private Goods, January 2004

1122 Martin Peitz and Patrick Waelbroeck, The Effect of Internet Piracy on CD Sales: CrossSection Evidence, January 2004

1123 Ansgar Belke and Friedrich Schneider, Privatization in Austria: Some Theoretical Reasons and First Results About the Privatization Proceeds, January 2004

1124 Chang Woon Nam and Doina Maria Radulescu, Does Debt Maturity Matter for Investment Decisions?, February 2004

1125 Tomer Blumkin and Efraim Sadka, Minimum Wage with Optimal Income Taxation, February 2004

1126 David Parker, The UK's Privatisation Experiment: The Passage of Time Permits a Sober Assessment, February 2004

1127 Henrik Christoffersen and Martin Paldam, Privatization in Denmark, 1980-2002, February 2004

1128 Gregory S. Amacher, Erkki Koskela and Markku Ollikainen, Deforestation, Production Intensity and Land Use under Insecure Property Rights, February 2004

1129 Yin-Wong Cheung, Javier Gardeazabal, and Jesús Vázquez, Exchange Rate Dynamics: Where is the Saddle Path?, February 2004

1130 Alberto Alesina and Guido Tabellini, Bureaucrats or Politicians?, February 2004

1131 Gregory S. Amacher, Erkki Koskela, and Markku Ollikainen, Socially Optimal Royalty Design and Illegal Logging under Alternative Penalty Schemes, February 2004

1132 David M. Newbery, Privatising Network Industries, February 2004 